\title{
Heavy metal pollution in urban-grown organic vegetables and soils of
}

\section{the province of Sevilla, Spain}

Rafael López ${ }^{\mathrm{a}}$, Juana Hallat ${ }^{\mathrm{a}}$, Asunción Castro ${ }^{\mathrm{a}}$, Adolfo Miras ${ }^{\mathrm{b}}$, Pilar Burgos $^{\mathrm{a}}$

${ }^{a}$ Instituto de Recursos Naturales y Agrobiología de Sevilla (IRNAS-CSIC), Sevilla,

Spain. ${ }^{\mathrm{b}}$ Dep. Cristalografia, Mineralogía y Química Agrícola, Universidad de Sevilla, Sevilla, Spain.

juani_almen_14@hotmail.com; acastro@irnase.csic.es; amiras@us.es; pburgos@irnase.csic.es

*Corresponding author: Rafael López

Avda. Reina Mercedes 10, 41012-Sevilla, Spain

Tel: +34 954624711

E-mail address: rafael.lopez@csic.es

\section{Acknowledgements}

This work was supported by the Spanish Ministry of Economy, Industry and Competitiveness and the European Regional Development Fund, European Union (Project CGL2016-76498-R). The authors wish to thank the anonymous farmers for their kind cooperation and the anonymous reviewers and the editor for their valuable comments.

\section{Preprint submitted to: Taylor \& Francis}




\section{Heavy metal pollution in urban-grown organic vegetables and soils of the province of Sevilla, Spain}

Sources of heavy metal pollution in vegetables can be varied. The focus of this study was to determine the factors affecting trace metal pollution in soils and vegetables that are grown on community urban and periurban organic farms in Spain. Results of this study shown that soil and dust deposition affected plant composition more than other anthropogenic sources, such as traffic loads, which showed a small incidence on the farm located in the largest city, Sevilla. Lettuce and broad bean samples taken at one urban farm showed high concentrations of crustal metals $\mathrm{Fe}, \mathrm{Ca}, \mathrm{Mn}$ and $\mathrm{Cr}$, which was thought be due to Saharan dust deposition. The buildup of soil $\mathrm{Cu}$ concentration, due to the use of $\mathrm{Cu}$-based fungicide over the long term, was observed on the farm where cultivation had occurred over a long period of time. On this farm, $\mathrm{Pb}$ in soil and vegetables had reached levels that could pose a risk to human health and/or the environment due to the random and uncontrolled locations of the disposal of demolition wastes containing lead-based white paints. The increased risks for consumers due to these several sources acting simultaneously demonstrate the need for a careful selection of the urban soils that are intended for agricultural use. Soil organic matter counteracted $\mathrm{Pb}$ availability, hence organic management and intensive use of organic amendments are recommended for urban farms.

Keywords: Urban agriculture; organic agriculture; lead; construction and demolition wastes; paint; Saharan dust

\section{Introduction}

Urban agriculture is a growing activity in many cities on a worldwide scale (Meharg 2016; Gliessman 2017). Urban agriculture is practiced in both developed and developing economies although it can serve different purposes, such as recreation or

\section{Preprint submitted to: Taylor \& Francis}


food security (FAO 2016). Under both approaches, there is a revitalised interest in research concerning urban agriculture from a variety of perspectives including landscaping and urban planning (Matos and Batista 2013; Pfeiffer et al. 2015), social and economic aspects (Golden 2013; Larder et al. 2014; Rogus and Dimitri 2015), health and environment (Pearson et al. 2010; Watson and Moore 2011), ecological footprint (Wascher and Jeurissen 2017) as well as technical subjects (Anglade et al. 2016).

The debate on the advantages and disadvantages of urban agriculture is open. There are many and well-documented benefits of urban agriculture in terms of subsistence survival, food sovereignty and security, reduced food transportation distance, carbon sequestration, potentially-reduced urban heat island (UHI) effect, improved physical and mental health, improved aesthetics, community building, employment opportunities, improved local land prices, shortened supply chains and, thus, reduced price differentials between producers and consumers, provision of habitat for wildlife, and waste recycling (Mok et al. 2014; Carlet et al. 2017).

A major concern of urban agriculture lies in the risk contamination from pollution. Fruits and vegetables grown in cities can be polluted by undesirable organic or inorganic substances (Bretzel et al. 2016; Meharg 2016). Several studies have focused on the trace elements found in urban fruits and vegetables and where the elements were deemed to originate from different sources (Sharma et al. 2008; HeidaryMonfared 2011; Säumel et al. 2012). One of the most important sources is air pollution due to vehicle traffic. Nevertheless, it is currently considered that the impact of air pollution on urban agriculture is not a serious problem in the developed world. The results of a study by Kohrman and Chamberlain (2014), of heavy metal contents in vegetables grown in the San Francisco Bay Area, USA, indicate that consumers can be 
confident in the urban community farm produce. These authors suggest that the results from their study could likely be extended to other cities with similar levels of pollution and heavy metals in the environment. Similarly, Arrobas et al. (2016) found that trace metal concentrations were low in the soil of a Portuguese university farm and, as a result, the concentrations were low in the edible plant parts. However, in contrast to the former studies, Säumel et al. (2012) noted that there could be contradictory results due to differences in the local configuration affecting the metal concentration in plants. The authors state that on-site field studies in urban areas are still rather scarce but would be crucial for determining the health risks of urban horticulture.

The present study was focused on determining the levels of trace-metal pollution in soils and vegetables grown on urban organic farms in relation to differing prevailing conditions in each individual farm. The farms are located in SW Spain under Mediterranean climatic conditions in municipalities which differ in the number of inhabitants

\section{Materials and Methods}

\section{Urban farm selection}

This study was undertaken in municipalities of the Sevilla province, SW Spain. The study sites were situated on three urban farms, located in the cities of Sevilla (Miraflores park, here after MI, 37²4'55.8'N 557'44.4”W), Utrera (Fifth Centenary park, here after UT, $37^{\circ} 11^{\prime} 41.4^{\prime \prime} \mathrm{N} 5^{\circ} 45^{\prime} 59.0^{\prime \prime} \mathrm{W}$ ) and Almensilla (here after AL, $37^{\circ} 18^{\prime} 50.8^{\prime \prime} \mathrm{N} 6^{\circ} 07^{\prime} 01.6^{\prime \prime} \mathrm{W}$ ) and one periurban farm located in Osuna (here after OS, $37^{\circ} 14^{\prime} 59.6^{\prime \prime} \mathrm{N} 5^{\circ} 07^{\prime} 04.4^{\prime \prime} \mathrm{W}$ ) (Figure 1). The farms had been subdivided into small lots (ca. $100 \mathrm{~m}^{2}$ ) which were assigned to non-professional farmers (amateur growers), usually retired or unemployed individuals. The growers were asked to follow organic 
agricultural practices. Climatic conditions and height above sea level were similar for all of the farms. The prevailing winds are of NE direction in the months of JanuaryFebruary, and SW direction in the months between May and August (Windfinder 20092018). Geologically, all of the farms are situated in the Upper Cenozoic Guadalquivir basin, except MI that corresponds to Quaternary fluvial terrace materials (Sand de Galdeano and Vera 1992). AL, UT and OS sites correspond to Upper Miocene sediments (Messinian 5 m.a.) (Mayoral and Abad 2008). The geological map is provided as supplementary material (Figure S1). The farms differed in their relative positions within the cities, the distances to roads and other infrastructure and the total population count of the respective cities. These main differences are summarised in Table 1. Detailed maps of the sites are provided as supplementary material (Figures S2 to S5).

\section{[Insert Table 1 near here]}

\section{Plant and soil sampling}

Five lots (allotments) were selected at each of AL, OS and UT farms and soil, lettuce and bean samples were collected in each lot. Eight lots were selected at MI site in which 8 soil samples, 7 lettuce samples and 5 bean samples were taken. Furthermore, at MI site, 4 additional soil samples were taken in nearby positions (at less than 10-20 m from cultivated plots) corresponding to a garden area outside of the cultivated land (see Supplementary Figure S5). These samples were named MIg. The samples were taken during the winter and early spring seasons of 2016, with the exception of three bean samples and two complete (inner and outer leaves) lettuce samples from MI that were taken during the winter season in early 2017. 
Several vegetables and legumes were cultivated in rows at each individual lot, depending on season and owner preference. At the first sampling date, broad bean (Vicia faba) was a common legume in many of the plots and romaine lettuce (Lactuca sativa var. longifolia) was the most common non-leguminous vegetable. Hence, these two plant species were selected for the study. However, although the capacity for uptake, accumulation and tolerance of trace metals could differ between cultivars of the same crop species (Alexander et al. 2006; Arrobas et al. 2016), the growers were not able to confirm the names of the bean cultivars used.

The pods of beans were sampled and they were processed as a whole (including beans and pericarp) as this is the way they are consumed in the region. In the case of lettuce, only the outer wrapper leaves (Mills and Jones 1996) were taken, with the exception of 5 samples corresponding to MI site for which also the inner leaves were sampled and separately analysed.

European regulations which set the maximum levels of contaminants in foodstuffs (European Commission 2006b) indicate the maximum levels allowed after fruit and vegetables have been washed. Accordingly, plant samples were gently washed to remove surface contamination by dipping first in tap water and then twice in deionised water.

Soil samples (0-15 cm depth) were taken in each of the lots by combining samples from 3 points in the corresponding lettuce row.

Most of the farmers apply high doses of manure or compost amendments each year (2016 personal interviews with growers; unreferenced) and therefore available samples of manure and compost that was currently being used by the farmers were also taken. The heavy metal concentrations in these samples (shown in supplementary Table S1) were lower than the maximum limits as stated by the European Union for use in 
organic agriculture (European Commission 2006a). A number of farmers also used commercially available fertilizers (unreferenced) whose use was approved for organic farming (European Commission 2006a).

[Insert Figure 1 near here]

\section{Plant and soil analyses}

Plant samples were dried at $70^{\circ} \mathrm{C}$, the moisture content was determined, and the samples were ground to pass through a $0.5 \mathrm{~mm}$ sieve and were then digested by wet oxidation with high purity concentrated $\mathrm{HNO}_{3}$ under pressure in a microwave oven (Ethos One, Millestone Srl, Sorisole, Italy) (Miller 1998). Mineral nutrients (P, K, Ca, $\mathrm{Mg}$ and S) and trace elements were determined by ICP-OES (Varian ICP 720-ES, Agilent Technologies, Santa Clara, California, USA) and expressed on a dry weight (DW) basis (Dahlquist and Knoll 1978). Concentrations of $\mathrm{Cd}$ and $\mathrm{Pb}$ were also expressed on a fresh weight basis ( $\mathrm{Cd} \mathrm{FW}$ and $\mathrm{Pb} \mathrm{FW})$ Total nitrogen was determined by spectrophotometry in a flow autoanalyser (AA3, Bran+Luebbe, Nordesrstedt, Germany) after Kjeldahl digestion.

Soil samples were air-dried and sieved through a $2 \mathrm{~mm}$ sieve. Soil organic matter (SOM) concentration was determined by the Walkley-Black wet combustion method (Nelson and Sommers 1982). Aqua regia extracts for element analysis (pseudototal concentration of $\mathrm{Al}, \mathrm{B}, \mathrm{Ba}, \mathrm{Ca}, \mathrm{Cd}, \mathrm{Co}, \mathrm{Cr}, \mathrm{Fe}, \mathrm{K}, \mathrm{Mg}, \mathrm{Mn}, \mathrm{Na}, \mathrm{Ni}, \mathrm{P}, \mathrm{Pb}, \mathrm{S}, \mathrm{Sr}, \mathrm{V}$ and $\mathrm{Zn}$ ) were obtained by microwave-assisted digestion of soil subsamples that had been previously ground finer than $0.5 \mathrm{~mm}$. Extractable metals $(\mathrm{Pb}, \mathrm{Zn}, \mathrm{Ni}, \mathrm{Cu}, \mathrm{Mn}, \mathrm{Ca}$, $\mathrm{Mg}, \mathrm{Ba}$ ) with the chelating agent EDTA (Ethylenediaminetetraacetic acid) were determined in MI samples by shaking $2.5 \mathrm{~g}$ of soil with $25 \mathrm{ml}$ of $0.05 \mathrm{~mol} \mathrm{l}^{-1}$ EDTA at $\mathrm{pH} 7$ for $1 \mathrm{~h}$ (Ure et al. 1993). In order to find a direct connection between the $\mathrm{Pb}$ and 
its hypothesised source, the particles coarser than $5 \mathrm{~mm}$ in $10 \mathrm{~L} \mathrm{MI}$ soil samples were sorted by hand. Samples of approximately $150 \mathrm{~g}$ of these coarse fragments were also extracted with EDTA and the extracts were analysed for metals.

For quality control of analytical procedures plant and soil samples from the Wageningen Evaluating Programmes for Analytical Laboratories (Houba et al. 1996) were analysed along with the samples. The results obtained for these control samples agreed $\pm 5 \%$ with the certified results.

\section{Statistical analysis and interpretation of soil results}

Comparisons of treatments were made by using Tukey's or Tamhane's test depending on data normality after one-way ANOVA. Comparisons of inner vs. outer lettuce leaves were performed using a paired-samples t-test. Multiple linear regression was used to model some parameters. Calculations were carried out by SPSS v.22 provided by SPSS Inc.

Two sets of reference values were considered for the interpretation and assessment of soil results. One set gives the reference values for soil metal concentrations in Andalucia (Southern Spain) (Aguilar-Ruíz et al. 1999). In this set, two values are given: the lower value is the threshold value (TV; indicating the need for further assessment); the higher value indicates that a treatment is needed (TN; action should be taken for soil remediation). The second set gives the reference values or guidelines corresponding to Finnish legislation on contaminated soil (MEF 2007). This set includes a threshold value (TV) and a lower guideline value (LGV) indicating ecological or health risks. These standards were chosen in accordance with the choice made in a recent study by Tóth et al. (2016) investigating the approaches used by European countries to define risk levels associated with different concentrations of 
heavy metal in soil, where the authors consider that the Finnish standard values represented a comprehensive approximation of the mean values of different national European systems. Both standards (plotted as horizontal lines in Figure 2) set similar values for the TV of $\mathrm{Cu}, \mathrm{Cr}$ and $\mathrm{Ni}$ but they do not match for $\mathrm{Zn}, \mathrm{Cd}$ and $\mathrm{Pb}$.

\section{Results and discussion}

\section{Metals in soils}

General characteristics of the soils of the four urban farms are shown in Table 2. Soils of the farms were calcareous, with average $\mathrm{pH}$ values of $8.2,7.8,7.8$ and 7.9 for $\mathrm{AL}$, UT, OS and MI sites respectively, and average soil carbonate content of 18.7, 8.8, 47.7 and $13.6 \%$ for AL, UT, OS and MI sites respectively.

Average metal concentrations in soils from the urban farms are shown in Figure 2 Data for additional elements are shown as supplementary material in Table S2. Only small differences were observed between AL, UT and OS soils according to their similar geological origin. The concentrations of all of the metals in AL, OS, and UT soils were well below the corresponding TV, TN and LGV for both standards (horizontal lines in Figure 2) and therefore, the AL, OS and UT garden soils were considered as unpolluted sites with no concern over metal contamination. Except in MI site, the levels of metals in the soils were even below the average geochemical background values given by Galan and Romero (2008) for the Guadalquivir valley materials.

[Insert Table 2 near here] 
However, soil from MI had higher concentrations of all of the metals, except $\mathrm{Cd}$ and $\mathrm{Ni}$, compared with that in soil from AL, OS and UT. The average Cu concentration in MI soil marginally exceeded the TV $\left(100 \mathrm{mg} \mathrm{kg}^{-1}\right)$ with $25 \%$ of samples exceeding the LGV for $\mathrm{Cu}$ and with no samples exceeding the TN. The LGV for $\mathrm{Cu}$ has been defined on the basis of ecological risks (Tóth et al. 2016) and, consequently, the MI site was considered as slightly polluted in relation to this metal. $\mathrm{Cu}$ is an element that is commonly associated with anthropogenic activities, and in the urban environment, it could be related to traffic pollution. The values corresponding to MIg in Figure 2 are the metal concentrations in soils of the nearby MI garden area (MIg) and they were used for comparison with MI soil. As MIg sampling points were located very close to the MI plots, it was assumed that both places were exposed to the same atmospheric deposition loads. However, the nearby MIg soils contained on average only $36 \mathrm{mg} \mathrm{Cu} \mathrm{kg}^{-1}$, which ruled out traffic as the sole source for this metal in MI soils. In organic agricultural management systems, several copper-based fungicides (European Commission 2008) are permitted and blue spots on some plant leaves, indicating application of $\mathrm{Cu}$ salts, were observed in several plots when the samples were taken. These observations were corroborated through discussions with the growers (unreferenced). Organic growers are prone to use $\mathrm{Cu}$-based products in a preventive way as they can be applied easily and safely by amateur growers without causing toxicity problems on the plants or the users and they are among only a few products that are permitted for use as fungicides in organic farming. Nevertheless, there is some concern regarding $\mathrm{Cu}$ accumulation in agricultural soils when it is used over long periods (Fishel 2014; Bretzel et al. 2016), as the data for the MI plots confirmed. This site had been under cultivation for a longer period (25 years, Table1) than the other urban farms, which may explain the rise in $\mathrm{Cu}$ concentrations. 


\section{[Insert Figure 2 near here]}

Lead pollution at the MI site was considered of great importance. Average (292

$\mathrm{mg} \mathrm{kg}^{-1}$ ), maximum and minimum $\mathrm{Pb}$ concentrations in MI soils far exceeded the values found in the other 3 urban farms (Figure 2). The average value for $\mathrm{Pb}$ was also greater than the median or mean concentrations of toxic metals in urban soils from some European cities, as compiled by Hiller et al. (2016) and Poggio et al. (2009). In a recent study by Antoniadis et al. (2017b) undertaken in four gardens located in the vicinity of a mine dump area in Germany, $\mathrm{Pb}$ was the single most important element causing a health risk related to consumption of vegetables grown in the gardens. In a study by Madrid et al. (2002), dealing with heavy metal contcentrations in garden soils of Sevilla, Alamillo Park which is located $3 \mathrm{~km}$ away from MI site, was considered as unpolluted background due to its unaltered status. The average $\mathrm{Pb}$ concentration in the MI plots $\left(292 \mathrm{mg} \mathrm{kg}^{-1}\right)$ was 6.7 times the calculated average concentration $\left(43 \mathrm{mg} \mathrm{kg}^{-1}\right)$ in topsoil $(0-20 \mathrm{~cm})$ at Alamillo park. The average $\mathrm{Pb}$ concentration for the MI site and around 88 $\%$ of MI samples taken exceeded the Andalusian TV and the Finnish LGV for $\mathrm{Pb}$ (200 $\mathrm{mg} \mathrm{kg}^{-1}$ ). The $\mathrm{LGV}$ for $\mathrm{Pb}$ has been defined on the basis of health risks (Tóth et al. 2016), and hence potential risks may arise for growers and consumers linked to several of the plots in the garden. It is well-known that $\mathrm{Pb}$ can cause adverse health effects through the food chain and via soil dust inhalation (Mielke et al. 1983; Kabata-Pendias and Pendias 2011). The most common sources of $\mathrm{Pb}$ compounds in contaminated soils are smelters, automobile exhaust (while leaded petrol was in use) and $\mathrm{Pb}$-containing paints (Kabata-Pendias and Pendias 2011). Before the transformation of MI site to a garden, the soil was previously on agricultural land and there is no evidence of nearby smelters or similar factories. There is a bypass highway, with 3 lanes per direction, near the site (Table 1) supporting about 100,000 vehicles/day (in the whole ring road) . This 
road was built in 1992 and after 2001 leaded petrol was banned in Spain. Hence, the pollution due to leaded petrol was thought to be an unlikely explanation for the high $\mathrm{Pb}$ concentrations found in the MI soils. Furthermore, if the $\mathrm{Pb}$ pollution was due to vehicle exhausts, it should also appear in the adjacent MIg control soils. However, the average $\mathrm{Pb}$ concentration in the MIg soils was $84 \mathrm{mg} \mathrm{kg}^{-1}$, which was greater than that in background Alamillo soils (43 $\mathrm{mg} \mathrm{kg}^{-1}$, calculated from Madrid et al. (2002)), but was well below the average $\left(292 \mathrm{mg} \mathrm{kg}^{-1}\right)$ for the MI plots. The most likely explanation for the high $\mathrm{Pb}$ concentration was the dumping of construction and demolition waste onto the site before the commencement of the urban farm situation. Coarse demolition waste can be readily observed in the soil of many of the plots. The orthophotograph of the site (Consejería de Medio Ambiente 2012), corresponding to the year 1977 (Figure 3), showed land degradation in this area, with adjacent white spots that are likely due to demolition waste. The orthophotograph corresponding to the year 1984 (Figure 3), showed that the land area corresponding to the current allotments was ploughed and that, possibly, the construction debris was mixed with soil, causing areas with a whitish colour to appear, mainly where farm roads are situated (selected areas in Figure 3). Finally, a filled creek (left side of plot area in the year 1984, Figure 3) was excavated once again (see image for the year 2016 in Figure 3) and its filling materials could have been displaced to the surrounding area. Demolition waste likely included white paints, the colour that is most commonly used for painting houses in Mediterranean countries. Basic lead carbonate, also known as white lead, or hydrocerussite $\left(2 \mathrm{PbCO}_{3} \cdot \mathrm{Pb}(\mathrm{OH})_{2}\right)$, formed the white pigment for lead paints (Clark et al. 2006). Walraven et al. (2016) notes that paints can have $\mathrm{Pb}$ concentrations in the range of $6.0-18.6 \%$. The problem of lead pollution in urban soils due to paints has already reported in the U.S.A. (DatkoWilliams et al. 2014; Mitchell et al. 2014; McBride 2016). However, in Europe, very 
few studies to date have reported and traced the input of anthropogenic $\mathrm{Pb}$ to soils that are used for domestic activities (Walraven et al. 2016). To the best of our knowledge, paints have not previously been considered an important source of $\mathrm{Pb}$ pollution in the Mediterranean countries, where white paints were supposedly based on limescale.

Other elements such as $\mathrm{Co}, \mathrm{Cr}, \mathrm{V}, \mathrm{Ba}, \mathrm{Sr}$ (Table $\mathrm{S} 2$ ) varied between the sites, but the concentrations of these were within the background ranges reported worldwide (Kabata-Pendias and Pendias 2011).

\section{Chemical availability of metals in Miraflores garden soil}

Extractable (i.e. available) metal concentrations in MI soils are shown in Table 3 and Table S3. The average ratio of the extractable concentration to total concentration, that is metal extractability, increased in the order $\mathrm{Cr}<\mathrm{Ni}<\mathrm{Mn}<\mathrm{Zn}<\mathrm{Cu}<\mathrm{Pb}<\mathrm{Cd}$, being on average greater than $30 \%$ for $\mathrm{Cu}, \mathrm{Pb}$, and $\mathrm{Cd}$. In a recent study, Różański et al. (2017) found that $\mathrm{Pb}$ was the most bioavailable and mobile element (mean PbDTPA $25.79 \%$ ). Nevertheless, opinion appears to differ as to whether $\mathrm{Pb}$ as a pollutant is a mobile (Poggio et al. 2009) or a stable soil component (Kabata-Pendias and Pendias 2011), since $\mathrm{Pb}$ extractability was found to vary widely between different studies (Antoniadis et al. 2017a). Such big differences in relation to metal availability would likely be due to their different origin and the different chemical forms in which they are present in soils. In MI soils, the high $\mathrm{Pb}$ extractability was in accordance with paints being the source of this metal, because $\mathrm{Pb}$ oxides and carbonate are the most soluble $\mathrm{Pb}$ compounds in soil environments, releasing small particles of $\mathrm{Pb}$ as the $\mathrm{Pb}$-based paint weathers in soils (Defoe et al. 2014). Natural weathering during the long period following the disposal of demolition wastes on this site ( $>25$ years, Table 1) would have favoured $\mathrm{Pb}$ release from the paints. Similar findings have been reported elsewhere; 
Walraven et al. (2016) explained the high oral $\mathrm{Pb}$ bio-accessibility of soil samples from Utrecht as being due to the small size and soluble primary $\mathrm{Pb}$ phases of $\mathrm{Pb}$ white paint particles. McBride (2016) noted that the extractable $\mathrm{Pb}$ fraction was larger in USA urban soils with greater total $\mathrm{Pb}$.

In order to find a direct connection between the $\mathrm{Pb}$ and its hypothesised source, the particles coarser than $5 \mathrm{~mm}$ in two $10 \mathrm{~L}$ MI soil samples were sorted by hand. Of these two soil samples, one corresponded with that which showed a high $\mathrm{Pb}$ concentration (410 $\mathrm{mg} \mathrm{kg}^{-1}$ ), and the other corresponded with that of a moderate $\mathrm{Pb}$ concentration $\left(245 \mathrm{mg} \mathrm{kg}^{-1}\right)$. The coarse particles consisted mainly of fragments of bricks and tiles and some small stones. The weight of coarse fragments obtained from the high $\mathrm{Pb}$ content soil was greater than that corresponding with a moderate $\mathrm{Pb}$ content (Table 4). Samples of approximately $150 \mathrm{~g}$ of these coarse fragments were extracted with EDTA and the extracts were analysed for metals (Table S4). The ratios of the EDTA metal contents in these samples between coarse fragments and the corresponding fine soil $(<2 \mathrm{~mm})$ are shown in Table 4. For the metals $\mathrm{Zn}, \mathrm{Ni}, \mathrm{Cu}, \mathrm{Mn}, \mathrm{Ca}$, and $\mathrm{Mg}$, these ratios were about $0.1-0.2$. For $\mathrm{Pb}$, the ratios were greater, 0.44 for the moderately $\mathrm{Pb}$-polluted sample and 0.79 for the highly $\mathrm{Pb}$-polluted sample. This indicated that $\mathrm{Pb}$ was associated with the debris occurring in the soils. Additionally, the element Ba also showed an elevated ratio debris/soil, that was greater than 1.1 in both samples. Average Ba concentration in MI soil (151 $\left.\mathrm{mg} \mathrm{kg}^{-1}\right)$ was also greater than in MIg soil (99 $\left.\mathrm{mg} \mathrm{kg}^{-1}\right)$ as well as in AL and UT soils (56 $\mathrm{mg} \mathrm{kg}^{-1}$, see Table S2). However, all these values were lower than the average world concentration (Kabata-Pendias and Pendias 2011). Barium sulphate (barite) is a common component of white paint pigments, such as lithopone (a mixture of barium sulphate and zinc oxide) (Walker et al. 2011). It is common to find the metals $\mathrm{Pb}, \mathrm{Ba}$ and also $\mathrm{Zn}$, together in paints and paint-polluted 
soils (Harroun et al. 2011; Turner and Lewis 2018; Walker et al. 2011) with $\mathrm{Pb}$ and $\mathrm{Ba}$ being highly available (Turner and Lewis 2018). Hence, the higher availability of $\mathrm{Pb}$ and $\mathrm{Ba}$ (Table 4) reinforced the hypothesis that paint was the source of $\mathrm{Pb}$ for the $\mathrm{MI}$ soil. It is also likely that the relatively high concentration of $\mathrm{Zn}$ in MI soils (Figure 2) could have been due to paints, at least in part.

[Insert Table 3 and Table 4 near here]

Linear correlation coefficients of the extractable EDTA-Pb and soil properties are shown in Table 5. The extractable EDTA-Ba was also included in the table because of the likely relationship between these metals. In MI soils, the extractable EDTA-Pb concentration increased linearly as total- $\mathrm{Pb}$ concentration increased, and weakly also as $\mathrm{pH}$ increased. The available Olsen- $\mathrm{P}\left(\mathrm{NaHCO}_{3}\right.$ extractable $)$ and $\mathrm{SOM}$, on the contrary, were inversely related to EDTA-Pb concentration, and there was not apparent relationship with EDTA-Ba concentration.

The positive relationship between EDTA-Pb and $\mathrm{pH}$ was contradictory to previous findings, because a high soil $\mathrm{pH}$ is known to favour $\mathrm{Pb}$ adsorption and this might promote $\mathrm{Pb}$ precipitation, making it less available for plant uptake but co-linearity effects would bias $\mathrm{pH}$ effect.

The two inverse relationships between EDTA-Pb and SOM and EDTA-Pb with Olsen-P could be seen as a single relationship because both, SOM and Olsen-P showed a high degree of co-linearity between them.

[Insert Figure 3 and Table 5 near here]

EDTA-Pb was modelled by multiple linear regression using SOM and EDTABa concentrations as independent variables. A good fit (adjusted $R^{2}=0.852, p=0.004$ ) was obtained by means of the following equation: 


$$
E D T A-P b=74.0+27.2 * E D T A-B a-1.47 \text { SOM }
$$

and EDTA-Pb and EDTA-Ba expressed in $\mathrm{mg} \mathrm{kg}^{-1}$ and SOM expressed in $\mathrm{g} \mathrm{kg}^{-1}$.

Equation 1 is plotted in Figure 4. The coefficient for the reverse relationship EDTA-Pb vs. SOM was highly significant $(p=0.002)$ while the coefficient for the effect of Ba-EDTA was slightly significant $(p=0.052)$. Equation 1 indicated that in MI soils, each gram of $\mathrm{SOM}$ reduced the $\mathrm{Pb}$ chemical availability by $1.5 \mathrm{mg} \mathrm{kg}^{-1}$. Thus, $\mathrm{SOM}$ played a role in protecting plants and people against $\mathrm{Pb}$ pollution. Equation 1 again indicated the relation between $\mathrm{Pb}$ and $\mathrm{Ba}$, suggesting a common origin.

[Insert Figure 4near here]

\section{Metals in the edible portion of plant samples}

Cocentrations of the micronutrients $\mathrm{Fe}, \mathrm{Cu}$ and $\mathrm{Zn}$ and the heavy metals $\mathrm{Cr}$, Ni, $\mathrm{Cd}$ and $\mathrm{Pb}$ in the bean pods and in the leaves of lettuce for each site are shown in Table 6. The concentrations of $\mathrm{Cd}$ and $\mathrm{Pb}$ were also expressed on a fresh weight basis $(\mathrm{Cd} \mathrm{FW}$ and $\mathrm{Pb} \mathrm{FW})$ in Table 7 in order to compare with the limits established in the European regulation for foodstuffs (European Commission 2006b).

In general, comparing the 4 urban gardens, MI bean and lettuce samples showed the highest concentrations of $\mathrm{Zn}$ (Table 6). The average $\mathrm{Zn}$ concentration in lettuce from the AL, UT and OS sites were close to the lower limit of the sufficiency range given by Mills and Jones (1996) for this lettuce variety. The Zn contents of all lettuce samples from the MI site were found in the sufficiency range. Concentrations of $\mathrm{Pb}$ and $\mathrm{Pb} \mathrm{FW}$ in lettuce from the MI were also the highest compared with the other sites (though the differences were only significant when comparing with those from the OS site. In MI 
bean pods, concentrations of $\mathrm{Pb}$ and $\mathrm{Pb} \mathrm{FW}$ were also the highest, although due to the variability of the results they were not statistically significant (at $p<0.05$ ). One sample of MI pods exceeded the maximum allowable limit value established in the European regulation (0.10 $\mathrm{mg} \mathrm{kg}^{-1} \mathrm{FW}$; European Commission 2006b). Two samples of MI lettuce also showed values greater than the allowable limit for lettuce $\left(0.30 \mathrm{mg} \mathrm{kg}^{-1}\right.$ FW). The samples showing these high values were taken from the plots which also showed the highest $\mathrm{Pb}$ soil concentrations, some exceeding $400 \mathrm{mg} \mathrm{kg}^{-1}$. These results were consistent with the higher $\mathrm{Zn}$ and $\mathrm{Pb}$ concentrations observed in the corresponding MI soils, which was concluded to have originated from painted demolition debris.

Concentrations of Cd and Cd FW in lettuce from the MI site (Table 6 and Table 7) were also the highest among the four garden sites, but in the case of $\mathrm{Cd} \mathrm{FW}$, the average value $\left(0.03 \mathrm{mg} \mathrm{kg}^{-1} \mathrm{FW}\right)$ was one order of magnitude lower than the allowable limit $\left(0.20 \mathrm{mg} \mathrm{kg}^{-1} \mathrm{FW}\right)$. Average Cd concentrations in lettuce from the MI site exceeded the common background range given by Kabata-Pendias and Pendias (2011). The concentrations of $\mathrm{Cd}$ in all of the samples from AL, OS and UT sites were below the tolerable concentrations for agronomic crops, in accordance with Kabata-Pendias and Pendias (2011).

Bean pod samples from OS and MI samples had a greater concentrations of $\mathrm{Ni}$ than AL and UT samples, in accordance with the Ni content of the soils (Table 6 and Figure 2). In general, the contents of $\mathrm{Ni}$ in all of the samples were below the tolerable concentrations for agronomic crops (Kabata-Pendias and Pendias 2011).

There were no significant differences between $\mathrm{Cr}$ concentrations in the plants from the different sites (Table 6). A number of samples of lettuce in all of the sites had a Cr concentration that was greater than the tolerable limit $\left(2 \mathrm{mg} \mathrm{kg}^{-1}\right)$, as indicated by 
Kabata-Pendias and Pendias (2011), although the concentrations were far below the excessive or toxic values $\left(5-30 \mathrm{mg} \mathrm{kg}^{-1}\right)$, as indicated by the same authors.

In lettuce, $\mathrm{Fe}$ and $\mathrm{Cu}$ concentrations showed a high variability (from 95 to 913 $\mathrm{mg} \mathrm{kg}^{-1}$ and from 5 to $525 \mathrm{mg} \mathrm{kg}^{-1}$, respectively). With regards to the Fe concentration, this could be due to dust deposition on the samples, corresponding to the UT site whichwere taken a few days after an event known as "red rain", a meteorological event carrying the aforementioned dust from North African sources. These rains are relatively frequent in Spain (on average 3 times per year) and other Mediterranean countries. A figure showing the intense dry deposition of dust in Spain, corresponding to 22 February 2016 (two days before sampling was undertaken at the UT site) obtained from the Barcelona Dust Forecast Center (2016) is included as supplementary material (Figure S7). Díaz-Hernández and Párraga (2008) monitored the atmospheric dust deposition for the period 1999-2005 in the city of Granada (192 km away from UT site) and they indicated that the bulk mineralogical composition of the dust in all of the events consisted largely of dolomite and quartz (>30\%), accompanied by calcite, gypsum, halite and illite in lower proportions (12-2\%); minor phases included beidellite, hematite, kaolinite, montmorillonite and albite $(<2 \%)$. There is large body of information concerning the Saharan dust transport (Karanasiou et al. 2012). In general, the composition of the red dust reflects that of the Earth's crustal composition in "pure" Saharan dust. Trace metals are generally depleted in the source material (values in the range 10-20 $\mathrm{mg} \mathrm{kg}^{-1}$ for $\mathrm{Cr}, \mathrm{Zn}$ and $\mathrm{Pb}$ and about $0.1 \mathrm{mg} \mathrm{kg}^{-1} \mathrm{Cd}$ ) (Guerzoni et al. 1997). Depending on its pathway, the original desert dust could change its composition and be enriched in anthropogenic components such as heavy metals. However, in a study on air quality (Consejería de Medio Ambiente 2012), it was indicated that the heavy metal concentrations in atmospheric particulate matter (PM10) taken during the 
period 2009-2012 in several sampling sites in Andalucía (Southern Spain) were relatively low and did not exceed the threshold legislative limits, which is in agreement with the low metal concentrations (except Fe) found in the UT plant samples (Table 6). The red rain did not affect AL samples because they were taken before the event occurred (Table 1). In the case of OS and MI samples, they were taken after the Spring (clean) rain, which probably washed away the red rain deposits.

As indicated in the previous section, the large variability and high values obtained for $\mathrm{Cu}$ concentrations were likely to be due to the use of copper-based fungicides. Therefore, the higher measured $\mathrm{Cu}$ concentrations in the leaves were likely to have been caused by foliar contamination from the applied spray. Although $\mathrm{Cu}$ found in urban plants is generally considered to be an element that is related to traffic pollution, any $\mathrm{Cu}$ enrichment due to traffic, if at all, was probably masked by that from the $\mathrm{Cu}$ fungicide. Because the inorganic forms of copper are relatively water-insoluble, they do not wash easily from foliage (Fishel 2014). European laws do not limit $\mathrm{Cu}$ concentrations in vegetables in relation to human consumption, although concentrations in plants greater than $20-100 \mathrm{mg} \mathrm{kg}^{-1}$ are considered as excessive or even as toxic to plants (Kabata-Pendias and Pendias 2011). No sign of plant toxicity, either due to $\mathrm{Cu}$ use or other metals, was observed in the urban vegetables during this work. This confirmed that measured $\mathrm{Cu}$ in the leaves must have been foliar contamination from an applied spray.

\section{[Insert Table 6 and Table 7 near here]}

Average concentrations of other nutrients (such as $\mathrm{P}, \mathrm{S}, \mathrm{Ca}, \mathrm{Mg}, \mathrm{K}, \mathrm{Na}, \mathrm{B}, \mathrm{V}$, $\mathrm{Co}$ ) as well as $\mathrm{Ba}$ and $\mathrm{Sr}$ determined in the plant samples are shown in Figure 5. In the bean pods, concentrations of $\mathrm{P}, \mathrm{S}, \mathrm{Ca}, \mathrm{Mg}, \mathrm{K}$ and $\mathrm{B}$ were relatively similar between the sites, with small differences attributable to the different sampling times between the 
sites. Concentrations of $\mathrm{Ba}$ in the pods from the AL sitewere abnormally high and there was no explanation for this. Concentrations of $\mathrm{Sr}$ in the bean pods and lettuce from the OS site were higher than those in the other sites, which was in agreement with the higher concentration of this element in the corresponding soil (Table S2).

In general terms, the average concentration of nutrients in the lettuce samples (Figure 5) from the urban gardens was higher than those in the commercial (market) lettuce samples used as a comparison. This fact could be due to the high fertility status of the urban garden soils which were rich in soil organic matter and available nutrients (see Table 2). The exception is $\mathrm{P}$, due to the calcic nature of the urban garden soils containing moderate concentrations of calcium carbonate (Table 2). The average nutrient concentrations were in the ranges recommended for lettuce, in accordance with Mills and Jones (1996).

[Insert Figure 5near here]

\section{Aerial deposition and direct plant uptake in Miraflores garden}

Despite the fact that the plant samples were always washed prior to analysis, the maximum Fe concentrations in lettuce samples from all sites (Table 6) were rather higher than the recommended range reported by Mills and Jones (1996) for longifolia variety. Such high values could indicate that the washing procedure was unable to completely remove the fine dust from "red rain" or soil particles that were bonded to the rough and very exposed surface of the wrapper leaves of the lettuce.

In order to assess the relative contribution of metals supplied to lettuce plants by aerial deposition and root absorption, two sets of comparisons were carried out in MI lettuce samples (Table 8). The first set compared wrapper leaves $v s$. inner leaves. Likely, the draped inner leaves would be free of metals that were supplied by aerial 
deposition. Accordingly, wrapper lettuce leaves showed significantly higher concentrations of several elements compared with the inner leaves (Table 8). The concentrations of $\mathrm{Fe}, \mathrm{Mn}, \mathrm{Cd}$ and $\mathrm{Cd} \mathrm{FW}$ were twice as high in the wrapper leaves in relation to the inner leaves, while $\mathrm{Pb}$ and $\mathrm{Pb} F W$ were three times greater in the wrapper leaves. Although the wrapper leaves may tend to accumulate nutrients and metals due to the fact that they are older than the inner leaves, such big differences were thought likely to be due to soil deposition on the outer part of the plants. Even so, the average Cd FW obtained in the group of wrapper samples was one order of magnitude lower than the maximum permitted level by European laws. In the case of $\mathrm{Pb} F W$, the average concentration in the wrapper leaves was also four times lower than the allowed limit but, it should therefore be taken into account that this group of lettuce samples were taken from moderately polluted plots (170 to $245 \mathrm{mg} \mathrm{Pb} \mathrm{kg}^{-1}$ ). Random physical contamination of plants by both soil and airborne particles is a common analytical problem for studies dealing with plant nutrition. It is also an important mechanism of $\mathrm{Pb}$ transfer to vegetables and other crops because of the fact that only minimal soil particle contamination of vegetables by high-Pb soil particles could greatly increase concentrations of $\mathrm{Pb}$ in the edible portion of the crop (McBride et al. 2013). Nevertheless, from a toxicological point of view, the risk from $\mathrm{Pb}$ for the edible portion of vegetables is a result of both lead-contaminated particles attached to the plant surface and direct uptake into the plant tissue (Finster et al. 2004). From the average Pb FW concentrations in inner and wrapper leaves of lettuce (Table 8), an estimate of $\mathrm{Pb}$ due to direct plant uptake would be $8.7 \%$ and that due to soil deposition would be $15.7 \%$ (average soil $\mathrm{Pb}$ concentration $210 \mathrm{mg} \mathrm{kg}^{-1}$ ) in relation to the European permitted limit in foodstuffs $\left(0.30 \mathrm{mg} \mathrm{kg}^{-1} \mathrm{FW}\right.$.). 
A second comparison was carried out between inner lettuce leaves from MI garden and commercial lettuces in the marketplace that were cultivated in conventional non-organic farms in the same province. Inner leaves of MI lettuces showed higher $\mathrm{Pb}$ concentrations but lower Ni concentrations than market lettuce (Table 8). Although it was considered that the uptake of $\mathrm{Pb}$ via roots is usually very low in neutral and organic-rich soils (McBride et al. 2013), in the moderately Pb-polluted MI-soils, the uptake in lettuce was three times the actual uptake in lettuce grown in agricultural soils that are likely to be unpolluted. The origin of the $\mathrm{Pb}$ problem, that is the paints, and the high chemical $\mathrm{Pb}$-extractability explained the physiological increase in $\mathrm{Pb}$ content.

Concentrations of $\mathrm{Zn}$ and $\mathrm{Cu}$ were also greater in MI samples, but differences in relation to market samples were not significant due to data variability. For $\mathrm{Pb} F W$, the MI samples showed more than twice the average concentration than that in the market samples, but the differences were not significant due to the varied moisture content of market lettuces.

[Insert Table 8 near here]

\section{General comments}

Several ways of affecting the metal concentrations of vegetables grown in urban farms have been determined, some of which have rarely been reported to date in European cities and which are able to cause important threats to consumers of urban products. The aerial deposition of airborne particles coming from long distances (e.g. Saharan dust) affected the metal composition of vegetables under the semiarid conditions prevailing in southern Spain. Currently, this "red dust" added crustal elements and produced small increases in some heavy metals, though unlikely to pose any risk to human health. A second pathway leading to soil $\mathrm{Cu}$ enrichment was traced to the continued use of copper fungicides, which are allowed under the organic farming system. 
Nevertheless, in the present study, spotty soil pollution due to $\mathrm{Pb}$ (and $\mathrm{Zn}$ ) was also observed in the MI urban farm located in Sevilla city. The soil was likely polluted by the disposal of demolition waste containing lead-based white paints in the former farmland soil. As a result, lettuce and broad bean showed high $\mathrm{Pb}$ content due to current $\mathrm{Pb}$ transfer through airborne particulate deposition of soil particles, and root absorption. Plant $\mathrm{Pb}$ concentrations may reach potentially dangerous levels in the more polluted soil $\left(\sim 400 \mathrm{mg} \mathrm{kg}^{-1}\right)$. Generally, in the case of the vegetables grown in urban gardens and courtyards, several factors may raise the likelihood of $\mathrm{Pb}$ (as well as other metals) ingestion by humans: (1) vegetables are not marketed through conventional supply chains and they do not undergo factory washing, (2) transport distances and times are short and the external damage of the vegetables is therefore minimal, which avoids unnecessary discarding of external parts of the vegetables, (3) growers are confident that their products do not contain pesticides, hence, they could avoid careful rinsing of vegetables, (4) growers often "hand" prepare their products in the garden, thus increasing the probability of contact with soil (usually, the reason for this practice is to recycle vegetable wastes by "in situ" composting). The risks could increase in arid or semiarid weather conditions, such as those prevailing in Mediterranean countries for most of the year, which favours the generation of airborne dust. Under these circumstances, $\mathrm{Pb}$ pollution would pose a serious risk, taking into consideration that in community gardens the growers retain their plots for several years, thus they are consuming their own vegetables on a continuous basis. Soil pollution due to paints has been reported many times in the U.S.A., but rarely elsewhere to date. However, it could be a more widespread problem which is affecting the increasing number of urban farms all over the world.

\section{Conclusions}


In three of the four investigated urban farms, corresponding to smaller cities, metal concentrations were low in the soils than the limits set by national and international legislations. As a result, the concentrations of metals in the edible plant parts were also low.

Nevertheless, in the farm located in the largest city (Sevilla, 700,000 inhabitants), there was evidence of $\mathrm{Cu}$ accumulation in the soil, due to the continuous use of $\mathrm{Cu}$-based fungicides for over 25 years, and there is also evidence of $\mathrm{Pb}$ pollution, in soil and vegetables, due to the disposal of paint waste. Even after a prior assessment of metal pollution on a farm, this form of $\mathrm{Pb}$ pollution could be difficult to detect due to its random nature. Of course, the knowledge of land use history could help detect similar problems due to non-homogeneous sources of pollution.

Obviously, $\mathrm{Pb}$ pollution creates an undesirable situation in this garden environment, requiring corrective actions, but the results of the present study highlighted how soil organic matter decreased $\mathrm{Pb}$ extractability in the soil. Hence, organic farming methods, and specifically practices enhancing soil organic matter concentrations, can be recommended as a precautionary action on urban farms. The high extractability-bioavailability of $\mathrm{Pb}$, which originated from white paints, as well as other heavy metals, would need the research of methods of immobilisation or detoxification to be highly effective on polluted farms or alternatively, methods which isolate the polluted soil (e.g. raised beds).

\section{References}

Aguilar-Ruíz J, Dorronsoro-Fernández C, Gómez-Ariza J, Galán-Huertos E. 1999. Los criterios y estándares para declarar un suelo contaminado en Andalucía y la metodología y técnicas de toma de muestra y análisis para su investigación. [Andalusian standard 
and assessment criteria to declare a soil is contaminated] Sevilla, Spain: Consejería de Medio Ambiente de la Junta de Andalucía.

Alexander PD, Alloway BJ, Dourado AM. 2006. Genotypic variations in the accumulation of $\mathrm{Cd}, \mathrm{Cu}, \mathrm{Pb}$ and $\mathrm{Zn}$ exhibited by six commonly grown vegetables. Environ Pollut. 144:736-745.

Anglade J, Medina MR, Billen G, Garnier J. 2016. Organic market gardening around the Paris agglomeration: agro-environmental performance and capacity to meet urban requirements. Environ Sci Pollut Res. 1-10.

Antoniadis, V., Levizou, E., Shaheen, S.M., Ok, Y.S., Sebastian, A., Baum, C., Prasad, M.N.V., Wenzel, W.W., Rinklebe, J. 2017a. Trace elements in the soil-plant interface: Phytoavailability, translocation, and phytoremediation-A review. Earth-Science Rev. 171:621-645.

Antoniadis V, Shaheen SM, Boersch J, Frohne T, Du Laing G, Rinklebe J. 2017b. Bioavailability and risk assessment of potentially toxic elements in garden edible vegetables and soils around a highly contaminated former mining area in Germany. J Environ Manag. 186, Part 2:192-200.

Arrobas M, Lopes H, Rodrigues MÂ. 2016. Urban agriculture in Bragança, Northeast Portugal: assessing the nutrient dynamic in the soil and plants, and their contamination with trace metals. Biol Agric \& Hortic. 1-13.

Barcelona Dust Forecast Center. 2016 . Barcelona, Spain. Agencia Estatal de Meteorología [accessed 2018, Jan 8]. https://dust.aemet.es/forecast/nmmb-bsc-dustforecast-dust-dry-deposition

Bretzel F, Calderisi M, Scatena M, Pini R. 2016. Soil quality is key for planning and managing urban allotments intended for the sustainable production of homeconsumption vegetables. Environ Sci Pollut Res. 23(17):17753-17760. 
Carlet F, Schilling J, Heckert M. 2017. Greening U.S. legacy cities: urban agriculture as a strategy for reclaiming vacant land. Agroecology and Sustainable Food Systems.1-20. Clark HF, Brabander DJ, Erdil RM. 2006. Sources, sinks, and exposure pathways of lead in urban garden soil. J Environ Qual. 35(6):2066-2074.

Consejería de Medio Ambiente. 2012. Sevilla. Spain. Junta de Andalucía [accessed 2018,Jan 5].

http://www.juntadeandalucia.es/medioambiente/site/rediam/menuitem.aedc2250f6db83 cf8ca78ca731525ea0/?vgnextoid=0863d61 d8470f210 VgnVCM2000000624e50aRCRD Consejería de Medio Ambiente. 2005. Sevilla. Spain. Junta de Andalucía. Mapa Geológico de Andalucía (Geological Map of Andalucia) [accessed 2018,Jan 11]. http://www.juntadeandalucia.es/medioambiente/site/rediam/menuitem.

Dahlquist RL, Knoll JW. 1978. Inductively coupled plasma-atomic emission spectrometry: analysis of biological materials an soils for major, trace, and ultra-trace elements. Appl Spectrosc. 32(1):1-30.

Datko-Williams L, Wilkie A, Richmond-Bryant J. 2014. Analysis of U.S. soil lead (Pb) studies from 1970 to 2012. Sci Total Environ. 468-469:854-863.

Defoe PP, Hettiarachchi GM, Benedict C, Martin S. 2014. Safety of gardening on leadand arsenic-contaminated urban brownfields. J Environ Qual. 43(6):2064-2078. Díaz-Hernández JL, Párraga J. 2008. The nature and tropospheric formation of iberulites: Pinkish mineral microspherulites. Geochim Cosmochim Acta 72(15):38833906.

European Commission. 2006a. 2006/799/EC: Commission Decision of 3 November 2006 establishing revised ecological criteria and the related assessment and verification requirements for the award of the Community eco-label to soil improvers (notified 
under document number C(2006) 5369) Official J of the European Union L 325, 24112006 p. $28-34$.

European Commission. 2006b. Commission Regulation (EC) No. 1881/2006 setting maximum levels for certain contaminants in foodstuffs. Official J of the European Union L 364, 5-24.

European Commission. 2008. Commission Regulation (EC) No 889/2008 of 5 September 2008 laying down detailed rules for the implementation of Council Regulation (EC) No 834/2007 on organic production and labelling of organic products with regard to organic production, labelling and control. Official J of the European Union L250, 18/9/2008. p. 84.

FAO. 2016. HABITAT III. Revised Zero Draft of the new urban agenda. United Nations Conference on Housing and Sustainable Urban Development. Quito. Finster ME, Gray KA, Binns HJ. 2004. Lead levels of edibles grown in contaminated residential soils: a field survey. Sci Total Environ. 320(2-3):245-257.

Fishel FM. 2014. Pesticide Toxicity Profile: Copper-based Pesticides. [accessed August 4, 2016]. http://edis.ifas.ufl.edu.

Galán E, Romero A. 2008. Contaminación de Suelos por Metales Pesados. Macla 10: 48-60.

Guerzoni S, Molinaroli E, Chester R. 1997. Saharan dust inputs to the western Mediterranean Sea: depositional patterns, geochemistry and sedimentological implications. Deep Sea Res. Part II: Topical Studies in Oceanography 44: 631-654. Gliessman S. 2017. Special issue: Sustainable food planning and urban agriculture. Agroecol Sustain Food Syst.1-2. 
Golden S. 2013. Urban Agriculture Impacts: Social, Health, and Economic: A Literature Review Davis, California, USA: University of California Agriculture and Natural Resources.

Harroun SG, Bergman J, Jablonski E, Brosseau CL. 2011. Surface-enhanced Raman spectroscopy analysis of house paint and wallpaper samples from an 18th century historic property. Analyst 136: 3453-3460.

Heidary-Monfared S. 2011. Community Garden. Heavy Metal Study. Halifax: Environment Canada.

Hiller E, Lachká L, Jurkovič L, Ďurža O, Fajčíková K, Vozár J. 2016. Occurrence and distribution of selected potentially toxic elements in soils of playing sites: a case study from Bratislava, the capital of Slovakia. Environ Earth Sci. 75:1390.

Houba VJG, Uittenbogaard J, Pellen P. 1996. Wageningen Evaluating Programmes for Analytical Laboratories (WEPAL), organization and purpose. Commun Soil Sci Plant Anal. 27(3-4):421-431.

Kabata-Pendias A, Pendias H. 2011. Trace Elements in Soils ad Plants. 4 ed. Boca Raton, FL, USA: CRC Press.

Karanasiou A, Moreno N, Moreno T, Viana M, de Leeuw F, Querol X. 2012. Health effects from Sahara dust episodes in Europe: Literature review and research gaps. Environment International 47 (Supplement C):107-114

Kohrman H, Chamberlain CP. 2014. Heavy metals in produce from urban farms in the San Francisco Bay Area. Food Addit Contam: Part B 7(2):127-134.

Larder N, Lyons K, Woolcock G. 2014. Enacting food sovereignty: values and meanings in the act of domestic food production in urban Australia. Local Environ. 19(1):56-76. 
Madrid L, Díaz-Barrientos E, Madrid F. 2002. Distribution of heavy metal contents of urban soils in parks of Seville. Chemosphere 49(10):1301-1308.

Matos RS, Batista DS. 2013. Chapter 18, Urban Agriculture: The Allotment Gardens as Structures of Urban Sustainability. In: Özyavuz M, editor. Advances in Landscape Architecture. InTechOpen.

Mayoral, E., Abad, M. 2008. Geología de la Cuenca del Guadalquivir 2nd ed. in: Geología de Huelva. Lugares de interés geológico, (Ed.) Facultad de Ciencias Experimentales, Universidad de Huelva. Huelva Spain, pp. 20-27.

McBride MB. 2016. Extractability of $\mathrm{Pb}$ in urban gardens and orchards linked to soil properties. European J Soil Sci. 67(5):686-694.

McBride MB, Simon T, Tam G, Wharton S. 2013. Lead and arsenic uptake by leafy vegetables grown on contaminated soils: Effects of mineral and organic amendments. Water Air Soil Pollut. 224(1).

[MEF] Ministry of the Environment Finland 2007. Government Decree on the Assessment of Soil Contamination and Remediation Needs (214/2007, March 1, 2007). Meharg AA. 2016. Perspective: City farming needs monitoring. Nature. 531(7594):S60. Mielke HW, Anderson JC, Berry KJ, Mielke PW, Chaney RL, Leech M. 1983. Lead concentrations in inner city soils as a factor in the child lead problem. Am J Public Health 73(12):1366-1369.

Miller RO. 1998. Microwave digestion of plant tissue in a closed vessel. In: Kalra YP, editor. Handbook and Reference Methods for Plant Analysis. Boca Raton, New York: CRC Press.

Mills HA, Jones JB. 1996. Plant Analysis Handbook II. A Practical Sampling, Preparation, Analysis, and Interpretation Guide. Athens, Georgia, USA: MicroMacro Publishing. 
Mitchell RG, Spliethoff HM, Ribaudo LN, Lopp DM, Shayler HA, Marquez-Bravo LG, Lambert VT, Ferenz GS, Russell-Anelli JM, Stone EB et al. 2014. Lead (Pb) and other metals in New York City community garden soils: Factors influencing contaminant distributions. Environ Pollut. 187:162-169.

Mok HF, Williamson VG, Grove JR, Burry K, Barker SF, Hamilton AJ. 2014.

Strawberry fields forever? Urban agriculture in developed countries: A review. Agron Sustain Dev. 34(1):21-43.

Nelson DW, Sommers LE. 1982. Total Carbon, Organic Carbon, and Organic Matter. In: Page AL, Miller RH, Keeney DR, editors. Agronomy Monograph, Methods of Soil Analysis Part 2 Chemical and MicroBiol Properties. Madison, Wisconsin, USA: ASA, SSSA; p. 539-580.

Pearson LJ, Pearson L, Pearson CJ. 2010. Sustainable urban agriculture: stocktake and opportunities. Int J Agric Sustain. 8(1-2):7-19.

Pfeiffer A, Silva E, Colquhoun J. 2015. Innovation in urban agricultural practices: Responding to diverse production environments. Renew Agric Food Syst. 30(1):79-91. Poggio L, Vrščaj B, Schulin R, Hepperle E, Ajmone Marsan F. 2009. Metals pollution and human bioaccessibility of topsoils in Grugliasco (Italy). Environ Pollut. 157(2):680689.

Rogus S, Dimitri C. 2015. Agriculture in urban and peri-urban areas in the United States: Highlights from the census of agriculture. Renew Agric Food Syst. 30(1):64-78. Różański S, Jaworska H, Matuszczak K, Nowak J, Hardy A. 2017. Impact of highway traffic and the acoustic screen on the content and spatial distribution of heavy metals in soils. Environ Sci Pollut Res.1-9.

Sand de Galdeano, C, Vera, JA. 1992. Stratigraphic record and palaeogeographical context of the Neogene basins in the Betic Cordillera, Spain. Basin Res. 4(1):21-36. 
Säumel I, Kotsyuk I, Hölscher M, Lenkereit C, Weber F, Kowarik I. 2012. How healthy is urban horticulture in high traffic areas? Trace metal concentrations in vegetable crops from plantings within inner city neighbourhoods in Berlin, Germany. Environ Pollut. 165:124-132.

Sharma RK, Agrawal M, Marshall FM. 2008. Heavy metal (Cu, Zn, Cd and Pb) contamination of vegetables in urban India: A case study in Varanasi. Environl Pollut. $154(2): 254-263$.

Tóth G, Hermann T, Da Silva MR, Montanarella L. 2016. Heavy metals in agricultural soils of the European Union with implications for food safety. Environ Int. 88:299-309. Turner A, Lewis M. 2018. Lead and other heavy metals in soils impacted by exterior legacy paint in residential areas of south west England. Sci. Total Environ. 619-620: 1206-1213.

Ure AM, Quevauviller P, Griepink B. 1993. Speciation of heavy metals in soils and sediments an account of the improvement and harmonization of extraction techniques undertaken under the auspices of the bcr of the commission of the european communities. Int J Environ Anal Chem. 51(1-4):135-151.

Walker SR, Jamieson HE, Rasmussen PE. 2011. Application of synchrotron microprobe methods to solid-phase speciation of metals and metalloids in house dust. Environ Sci Technol. 45(19):8233-8240.

Walraven N, Bakker M, Vanos B, Klaver G, Middelburg JJ, Davies G. 2016. Pollution and oral bioaccessibility of $\mathrm{Pb}$ in soils of villages and cities with a long habitation history. Int J Environ Res Public Health. 13(2).

Wascher DM, Jeurissen L. 2017. Urban food security at the crossroads between metropolitan food planning and global trade: the case of the Antwerp-RotterdamDüsseldorf region. Agroecol Sustain Food Syst.1-21. 
Watson DLB, Moore HJ. 2011. Community gardening and obesity. Perspectives in Public Health. 131(4):163-164.

Windfinder. 2009-2018. Kiel, Germany: Winfinder.com GmbH \& Co. KG; [accessed 2018, May 15]. https://es.windfinder.com. Wind statistics for Sevilla airport were used. 
Table 1. Overview of urban farms

\begin{tabular}{|c|c|c|c|c|}
\hline Urban Farm & $\mathrm{MI}^{\mathrm{a}}$ & UT & OS & AL \\
\hline City & Sevilla & Utrera & Osuna & Almensilla \\
\hline Population in 2015 & 693,878 & 52,558 & 17,801 & 5,861 \\
\hline Distance to urban & -0.5 & -0.1 & +0.5 & 0.0 \\
\hline \multicolumn{5}{|l|}{ boundary $(\mathrm{km})^{\mathrm{b}}$} \\
\hline Distance to road $(\mathrm{km})$ & 0.1 & 0.1 & 0.0 & 0.2 \\
\hline Traffic density & very high & medium & low & low \\
\hline Nearby infrastructures & Railway (0.8) & Railway & Raft for & highway \\
\hline \multirow[t]{3}{*}{ (distance, $\mathrm{km}$ ) } & Industrial park & $(0.2)$ & brine $(0.2)$ & construction \\
\hline & $(0.3)$ & & Industrial & (1.6) \\
\hline & & & park $(0.5)$ & \\
\hline Plot surface $\left(\mathrm{m}^{2}\right)$ & 140 & 90 & 100 & 45 \\
\hline Time in use (years) & 25 & 9 & 8 & 4 \\
\hline \multirow[t]{3}{*}{ Sampling dates } & $17 / 05 / 2016$ & $24 / 02 / 2016$ & $27 / 04 / 2016$ & $05 / 02 / 2016$ \\
\hline & 08/06/2016 & $29 / 03 / 2016$ & & \\
\hline & $27 / 06 / 2016$ & & & \\
\hline
\end{tabular}

${ }^{\mathrm{a}}$ MI: Miraflores Park; ${ }^{\mathrm{b}}$ - indicates inside the city, + indicates outside the city 
Table 2. Characteristics of the soil ( \pm standard deviation) in the 4 urban gardens

\begin{tabular}{|c|c|c|c|c|c|}
\hline & & $\mathrm{AL}$ & UT & $\mathrm{OS}$ & MI \\
\hline $\mathrm{pH}^{\mathrm{a}}$ & & $8.2 \pm 0.2$ & $7.8 \pm 0.3$ & $7.8 \pm 0.2$ & $7.9 \pm 0.1$ \\
\hline E.C. ${ }^{b}$ & $\mathrm{mS} \mathrm{cm}{ }^{-1}$ & $0.23 \pm 0.14$ & $0.83 \pm 0.66$ & $0.22 \pm 0.04$ & $0.20 \pm 0.07$ \\
\hline $\mathrm{CaCO}_{3}$ & $\mathrm{~g} \mathrm{~kg}^{-1}$ & $18.7 \pm 8.2$ & $8.8 \pm 7.7$ & $47.7 \pm 4.5$ & $13.6 \pm 2.7$ \\
\hline O.M. ${ }^{\mathrm{c}}$ & $\mathrm{g} \mathrm{kg}^{-1}$ & $35.7 \pm 19.9$ & $38.6 \pm 19.9$ & $47.0 \pm 7.6$ & $49.2 \pm 14.3$ \\
\hline Kjeldahl-N & $\mathrm{g} \mathrm{kg}^{-1}$ & $0.19 \pm 0.09$ & $0.20 \pm 0.11$ & $0.25 \pm 0.04$ & $0.29 \pm 0.08$ \\
\hline Olsen-P & $\mathrm{mg} \mathrm{kg}^{-1}$ & $133 \pm 127$ & $115 \pm 127$ & $72 \pm 21$ & $93 \pm 65$ \\
\hline Fine sand & $\mathrm{g} \mathrm{kg}^{-1}$ & $35.9 \pm 2.6$ & $10.8 \pm 1.7$ & $12.1 \pm 1.0$ & $12.3 \pm 2.4$ \\
\hline Coarse sand & $\mathrm{g} \mathrm{kg}^{-1}$ & $20.8 \pm 2.6$ & $70.0 \pm 10.7$ & $29.4 \pm 4.4$ & $35.2 \pm 4.8$ \\
\hline Silt & $\mathrm{g} \mathrm{kg}^{-1}$ & $26.8 \pm 2.2$ & $7.0 \pm 5.4$ & $34.2 \pm 1.3$ & $27.0 \pm 2.0$ \\
\hline Clay & $\mathrm{g} \mathrm{kg}^{-1}$ & $16.5 \pm 2.3$ & $12.2 \pm 5.2$ & $24.2 \pm 2.6$ & $25.4 \pm 2.6$ \\
\hline Textural class & & Sandy loam & Loamy sand & Loam & Loam \\
\hline
\end{tabular}


Table 3. Extractable metal concentration in soils of Miraflores urban garden

\begin{tabular}{|c|c|c|c|c|c|c|c|c|}
\hline \multicolumn{2}{|l|}{ Concentration } & \multicolumn{7}{|c|}{ EDTA-Cr EDTA-Ni EDTA-Mn EDTA-Zn EDTA-Cu EDTA-Pb EDTA-Cd } \\
\hline Mean & $m g \mathrm{~kg}^{-1}$ & 0.13 & 0.59 & 56.2 & 23.5 & 33.0 & 90.1 & 0.12 \\
\hline Minimum & $\mathrm{mg} \mathrm{kg}^{-1}$ & 0.09 & 0.48 & 47.4 & 18.8 & 23.5 & 50.6 & 0.09 \\
\hline Maximum & $\mathrm{mg} \mathrm{kg}^{-1}$ & 0.18 & 0.70 & 73.2 & 28.6 & 59.3 & 130.9 & 0.15 \\
\hline \multicolumn{9}{|c|}{ Extractability $^{\mathrm{a}}$} \\
\hline Mean & $\%$ & 0.41 & 3.09 & 11.9 & 14.1 & 31.6 & 31.7 & 34.7 \\
\hline Minimum & $\%$ & 0.22 & 2.40 & 6.7 & 10.7 & 26.0 & 25.7 & 27.8 \\
\hline Maximum & $\%$ & 0.64 & 4.65 & 15.0 & 17.4 & 39.0 & 43.3 & 44.7 \\
\hline
\end{tabular}

${ }^{a}$ Extractability $=100 \times$ [extractable concentration] $/[$ total concentration] 
Table 4. Ratios of EDTA extractable metal concentration in coarse material ( $>5 \mathrm{~mm}$ ) to soil $(<2 \mathrm{~mm})$ in two allotments of Miraflores urban garden

\begin{tabular}{|c|c|c|c|}
\hline & & Sample $1^{\mathrm{a}}$ & Sample $2^{b}$ \\
\hline Total-Pb & $\mathrm{mg} \mathrm{kg}^{-1}$ & 410 & 245 \\
\hline Coarse fraction $(>5 \mathrm{~mm})$ & $\mathrm{g} \mathrm{L}^{-1}$ & 110 & 82 \\
\hline $\mathrm{Pb}$ ratio & & 0.792 & 0.440 \\
\hline $\mathrm{Zn}$ ratio & & 0.091 & 0.116 \\
\hline $\mathrm{Ni}$ ratio & & 0.082 & 0.112 \\
\hline $\mathrm{Cu}$ ratio & & 0.063 & 0.105 \\
\hline Mn ratio & & 0.176 & 0.180 \\
\hline $\mathrm{Ca}$ ratio & & 0.122 & 0.241 \\
\hline $\mathrm{Mg}$ ratio & & 0.153 & 0.180 \\
\hline Ba ratio & & 1.174 & 1.275 \\
\hline
\end{tabular}

${ }^{\mathrm{a}}$ Sample with a high $\mathrm{Pb}$ content; ${ }^{\mathrm{b}}$ Sample with a moderate $\mathrm{Pb}$ content 
Table 5. Pearson Correlations among $\mathrm{Pb}$ fractions and soil properties in Miraflores park soil samples

\begin{tabular}{|c|c|c|c|c|c|c|c|}
\hline & DTA-Pb & Total-Pb & $\mathrm{pH}$ & $\mathrm{CaCO}_{3}$ & $\mathrm{SOM}^{a}$ & Olsen-P & EDTA-Ba \\
\hline EDTA-Pb & 1 & $0.870^{* *}$ & $0.707^{*}$ & -0.311 & $-0.870^{* *}$ & $-0.898^{* *}$ & 0.479 \\
\hline Total-Pb & & 1 & $0.890^{* *}$ & 0.021 & $-0.719^{*}$ & $-0.778^{*}$ & 0.469 \\
\hline $\mathrm{pH}$ & & & 1 & -0.020 & -0.469 & -0.592 & 0.579 \\
\hline $\mathrm{CaCO}_{3}$ & & & & 1 & 0.238 & 0.308 & -0.650 \\
\hline $\operatorname{SOM}^{a}$ & & & & & 1 & $0.975^{* *}$ & -0.129 \\
\hline Olsen-P & & & & & & 1 & -0.277 \\
\hline
\end{tabular}

${ }^{a}$ SOM: Soil organic matter;

*Correlation is significant at the 0.05 level (2-tailed),

** Correlation is significant at the 0.01 level (2-tailed). 
Table 6. Metal concentrations ( $\mathrm{mg} \mathrm{kg}^{-1}$ dry basis) in pods of broad bean and lettuce taken from the urban gardens.

\begin{tabular}{|c|c|c|c|c|c|c|c|c|c|c|c|c|c|}
\hline \multirow{2}{*}{\multicolumn{2}{|c|}{ Site $^{\mathrm{a}}$}} & \multicolumn{3}{|c|}{ Broad (field) bean } & \multicolumn{6}{|c|}{ Lettuce } & \multirow{2}{*}{\multicolumn{2}{|c|}{$\pm \mathrm{sd}$}} & \multirow[b]{2}{*}{ Test $^{\mathrm{b}}$} \\
\hline & & & inge & Mean & \pm & sd & Tes & & Range & Mean & & & \\
\hline \multirow[t]{4}{*}{$\mathrm{Fe}$} & $\mathrm{AL}$ & 58.1 & -78.5 & 65.9 & \pm & 7.9 & $\mathrm{~b}$ & 95 & -280 & 208 & \pm & 85 & \\
\hline & OS & 34.6 & -45.6 & 39.9 & \pm & 5.3 & $\mathrm{a}$ & 109 & -409 & 212 & \pm & 125 & ns \\
\hline & UT & 53.7 & - 75.4 & 62.3 & \pm & 10.5 & $\mathrm{~b}$ & 114 & -913 & 392 & \pm & 326 & \\
\hline & MI & 49.1 & -80.4 & 65.0 & \pm & 11.5 & $\mathrm{~b}$ & 144 & -472 & 284 & \pm & 123 & \\
\hline \multirow[t]{4}{*}{$\mathrm{Cu}$} & $\mathrm{AL}$ & 9.6 & - 16.7 & 12.5 & \pm & 2.6 & & 7.88 & -154 & 45.5 & \pm & 62.0 & \\
\hline & OS & 8.5 & -40.1 & 18.0 & \pm & 12.7 & $\mathrm{~ns}$ & 6.44 & -525 & 112 & \pm & 231 & ns \\
\hline & UT & 6.7 & -12.9 & 10.4 & \pm & 2.7 & & 4.88 & $\begin{array}{ll}- & 17.7\end{array}$ & 9.3 & \pm & 4.8 & \\
\hline & MI & 9.5 & - 16.3 & 13.2 & \pm & 2.5 & & 7.08 & 36.2 & 14.5 & \pm & 10.0 & \\
\hline \multirow[t]{4}{*}{$\mathrm{Zn}$} & $\mathrm{AL}$ & 21.4 & - 26.4 & 23.7 & \pm & 2.2 & $\mathrm{a}$ & 16.4 & 38.5 & 22.2 & \pm & 9.3 & $\mathrm{a}$ \\
\hline & OS & 17.5 & -39.4 & 29.6 & \pm & 8.5 & $\mathrm{a}$ & 19.1 & 28.3 & 23.0 & \pm & 3.6 & $\mathrm{a}$ \\
\hline & UT & 27.6 & -34.7 & 29.5 & \pm & 3.5 & $\mathrm{a}$ & 14.1 & 26.7 & 19.7 & \pm & 4.5 & $\mathrm{a}$ \\
\hline & MI & 36.4 & -51.0 & 43.0 & \pm & 6.7 & b & 27.2 & 59.6 & 43.1 & \pm & 12.3 & $b$ \\
\hline \multirow[t]{4}{*}{$\mathrm{Cr}$} & $\mathrm{AL}$ & 0.34 & 1.57 & 0.60 & \pm & 0.55 & & 1.26 & 3.26 & 2.24 & \pm & 0.96 & \\
\hline & OS & 0.36 & $\begin{array}{ll}- & 1.09\end{array}$ & 0.62 & \pm & 0.30 & ns & 0.57 & 2.72 & 1.26 & \pm & 0.84 & ns \\
\hline & UT & 0.23 & - $\quad 0.46$ & 0.35 & \pm & 0.13 & & 0.48 & 5.55 & 2.21 & \pm & 1.95 & \\
\hline & MI & 0.30 & 0.81 & 0.43 & \pm & 0.21 & & 0.68 & 2.90 & 1.50 & \pm & 0.78 & \\
\hline \multirow[t]{4}{*}{$\mathrm{Ni}$} & $\mathrm{AL}$ & 0.73 & 1.53 & 1.16 & \pm & 0.30 & $\mathrm{a}$ & 0.72 & 1.50 & 1.12 & \pm & 0.36 & \\
\hline & OS & 1.69 & 3.03 & 2.20 & \pm & 0.55 & b & 0.46 & 2.55 & 1.11 & \pm & 0.84 & ns \\
\hline & UT & 0.73 & 1.07 & 0.94 & \pm & 0.15 & $\mathrm{a}$ & 0.58 & 2.46 & 1.21 & \pm & 0.74 & \\
\hline & MI & 1.16 & 2.57 & 1.77 & \pm & 0.68 & $a b$ & 0.45 & 1.54 & 0.91 & \pm & 0.37 & \\
\hline \multirow[t]{4}{*}{$\mathrm{Cd}$} & $\mathrm{AL}$ & 0.026 & 0.075 & 0.044 & \pm & 0.019 & & 0.048 & 0.237 & 0.177 & \pm & 0.076 & $5 a$ \\
\hline & OS & 0.012 & 0.047 & 0.027 & \pm & 0.016 & ns & 0.108 & 0.228 & 0.171 & \pm & 0.053 & $3 a$ \\
\hline & UT & 0.000 & 0.084 & 0.033 & \pm & 0.036 & & 0.091 & 0.224 & 0.186 & \pm & 0.055 & $5 a$ \\
\hline & MI & 0.009 & 0.050 & 0.031 & \pm & 0.016 & & 0.393 & 0.802 & 0.584 & \pm & 0.162 & $2 b$ \\
\hline \multirow[t]{4}{*}{$\overline{\mathrm{Pb}}$} & $\mathrm{AL}$ & 0.00 & 0.21 & 0.09 & \pm & 0.10 & & 0.62 & 1.33 & 1.00 & \pm & 0.25 & $a b$ \\
\hline & OS & 0.22 & 0.82 & 0.46 & \pm & 0.25 & ns & 0.25 & 1.40 & 0.68 & \pm & 0.50 & $\mathrm{a}$ \\
\hline & UT & 0.00 & 0.38 & 0.25 & \pm & 0.17 & & 0.51 & 1.21 & 0.80 & \pm & 0.33 & $\mathrm{a}$ \\
\hline & MI & 0.21 & 2.93 & 0.94 & \pm & 1.14 & & 0.61 & 6.50 & 3.14 & \pm & 2.35 & $\mathrm{~b}$ \\
\hline
\end{tabular}

${ }^{a}$ AL: Almensilla; OS: Osuna; UT: Utrera; MI: Miraflores Park in Sevilla city.

${ }^{\mathrm{b}}$ For each metal, mean values followed by the same letter do not differ significantly $(p>0.05)$, Tukey (Tu), log transform or Tamhane test was used depending on data normality; ns: nonsignificant. 
Table 7. Concentrations of $\mathrm{Pb}$ and $\mathrm{Cd}\left(\mathrm{mg} \mathrm{kg}^{-1}\right)$ expressed on a fresh weight basis (FW), in pods of broad bean and lettuce taken from the urban gardens.

\begin{tabular}{|c|c|c|c|c|c|c|c|}
\hline & \multicolumn{4}{|c|}{ Broad (field) bean } & \multicolumn{3}{|c|}{ Lettuce } \\
\hline & Site $^{a}$ & Range & Mean \pm sd & Test $^{b}$ & Range & Mean \pm sd & Test $^{b}$ \\
\hline $\mathrm{Cd}$ & $\mathrm{AL}$ & $0.004-0.010$ & $0.006 \pm 0.003$ & & $0.003-0.014$ & $0.010 \pm 0.004$ & $\mathrm{a}$ \\
\hline \multirow[t]{4}{*}{ FW } & OS & $0.001-0.006$ & $0.004 \pm 0.002$ & n.s. & $0.006-0.011$ & $0.008 \pm 0.002$ & $\mathrm{a}$ \\
\hline & UT & $0.001-0.011$ & $0.004 \pm 0.005$ & & $0.005-0.014$ & $0.011 \pm 0.004$ & $\mathrm{a}$ \\
\hline & MI & $0.001-0.006$ & $0.004 \pm 0.002$ & & $0.021-0.035$ & $0.028 \pm 0.006$ & $\mathrm{~b}$ \\
\hline & & ${ }^{\mathrm{c}}$ Limit $\quad 0.05$ & & & ${ }^{\mathrm{c}}$ Limit 0.20 & & \\
\hline $\mathrm{Pb}$ & $\mathrm{AL}$ & $0.000-0.027$ & $0.01 \pm 0.01$ & & $0.04-\quad 0.08$ & $0.06 \pm 0.01$ & $a b$ \\
\hline \multirow[t]{4}{*}{ F W } & OS & $0.030-0.090$ & $0.06 \pm 0.03$ & n.s. & $0.01-$ & $0.03 \pm 0.03$ & $\mathrm{a}$ \\
\hline & UT & $0.000-0.050$ & $0.03 \pm 0.02$ & & $0.03-$ & $0.05 \pm 0.02$ & $a b$ \\
\hline & MI & $0.014-0.510$ & $0.13 \pm 0.21$ & & $0.03-$ & $0.16 \pm 0.13$ & $\mathrm{~b}$ \\
\hline & & ${ }^{\mathrm{c}}$ Limit $\quad 0.10$ & & & ${ }^{\mathrm{c}}$ Limit 0.30 & & \\
\hline
\end{tabular}

${ }^{a}$ AL: Almensilla; OS: Osuna; UT: Utrera; MI: Miraflores Park in Sevilla city.

${ }^{\mathrm{b}}$ For each metal, mean values followed by the same letter do not differ significantly $(p>0.05)$, Tukey $(\mathrm{Tu}), \log$ transform or Tamhane test was used depending on data normality; n.s.: nonsignificant;

${ }^{\mathrm{c}}$ Maximum permitted levels by European Community legislation (European Commission, 2006). 
Table 8. Comparison of metal concentrations ( $\mathrm{mg} \mathrm{kg}^{-1}$ dry basis except $\mathrm{Cd} \mathrm{FW}$ and $\mathrm{Pb}$ FW expressed in a fresh weight basis) of inner leaves of lettuce purchased at supermarkets $(n=3)$ and grown in Miraflores urban garden $(n=5)$

\begin{tabular}{|c|c|c|c|c|c|}
\hline & $\begin{array}{l}\text { Wrapper } \\
\text { leaves }\end{array}$ & $p^{\mathrm{a}}$ & $\begin{array}{l}\text { Inner } \\
\text { leaves }\end{array}$ & t-test $p^{b}$ & Supermarket \\
\hline $\mathrm{Fe}$ & $179 \pm 81$ & $0.044 *$ & $94.6 \pm 24.7$ & 0.469 & $109 \pm 26$ \\
\hline $\mathrm{Mn}$ & $59.1 \pm 21.6$ & $0.038^{*}$ & $32.8 \pm 10.6$ & 0.428 & $42.4 \pm 16.1$ \\
\hline $\mathrm{Cu}$ & $9.92 \pm 4.10$ & 0.761 & $9.46 \pm 3.55$ & 0.061 & $5.02 \pm 1.91$ \\
\hline $\mathrm{Zn}$ & $44.3 \pm 13.3$ & 0.314 & $50.2 \pm 12.4$ & 0.206 & $32.3 \pm 17.2$ \\
\hline $\mathrm{Cr}$ & $1.01 \pm 0.64$ & 0.139 & $0.56 \pm 0.22$ & 0.393 & $0.97 \pm 0.67$ \\
\hline $\mathrm{Ni}$ & $0.60 \pm 0.26$ & 0.458 & $0.49 \pm 0.09$ & $0.044 *$ & $1.29 \pm 0.32$ \\
\hline $\mathrm{Cd}$ & $0.59 \pm 0.11$ & $0.022 *$ & $0.26 \pm 0.14$ & 0.676 & $0.22 \pm 0.13$ \\
\hline $\mathrm{Cd} \mathrm{FW}^{\mathrm{c}}$ & $0.03 \pm 0.01$ & $0.025^{*}$ & $0.01 \pm 0.01$ & 0.803 & $0.01 \pm 0.01$ \\
\hline $\mathrm{Pb}$ & $1.54 \pm 0.81$ & $0.035^{*}$ & $0.52 \pm 0.21$ & $0.017 *$ & $0.13 \pm 0.12$ \\
\hline $\mathrm{Pb} \mathrm{FW}^{\mathrm{c}}$ & $0.07 \pm 0.04$ & $0.034^{*}$ & $0.03 \pm 0.01$ & 0.089 & $0.01 \pm 0.01$ \\
\hline \multicolumn{6}{|c|}{${ }^{\mathrm{a}}$ paired t-test (2-tailed) } \\
\hline \multicolumn{6}{|c|}{$\begin{array}{l}\text { b Independent samples t-test, equal variances nor assumed } \\
\text { c Maximum permitted levels by European Community legislation (European }\end{array}$} \\
\hline
\end{tabular}




\section{Figure captions}

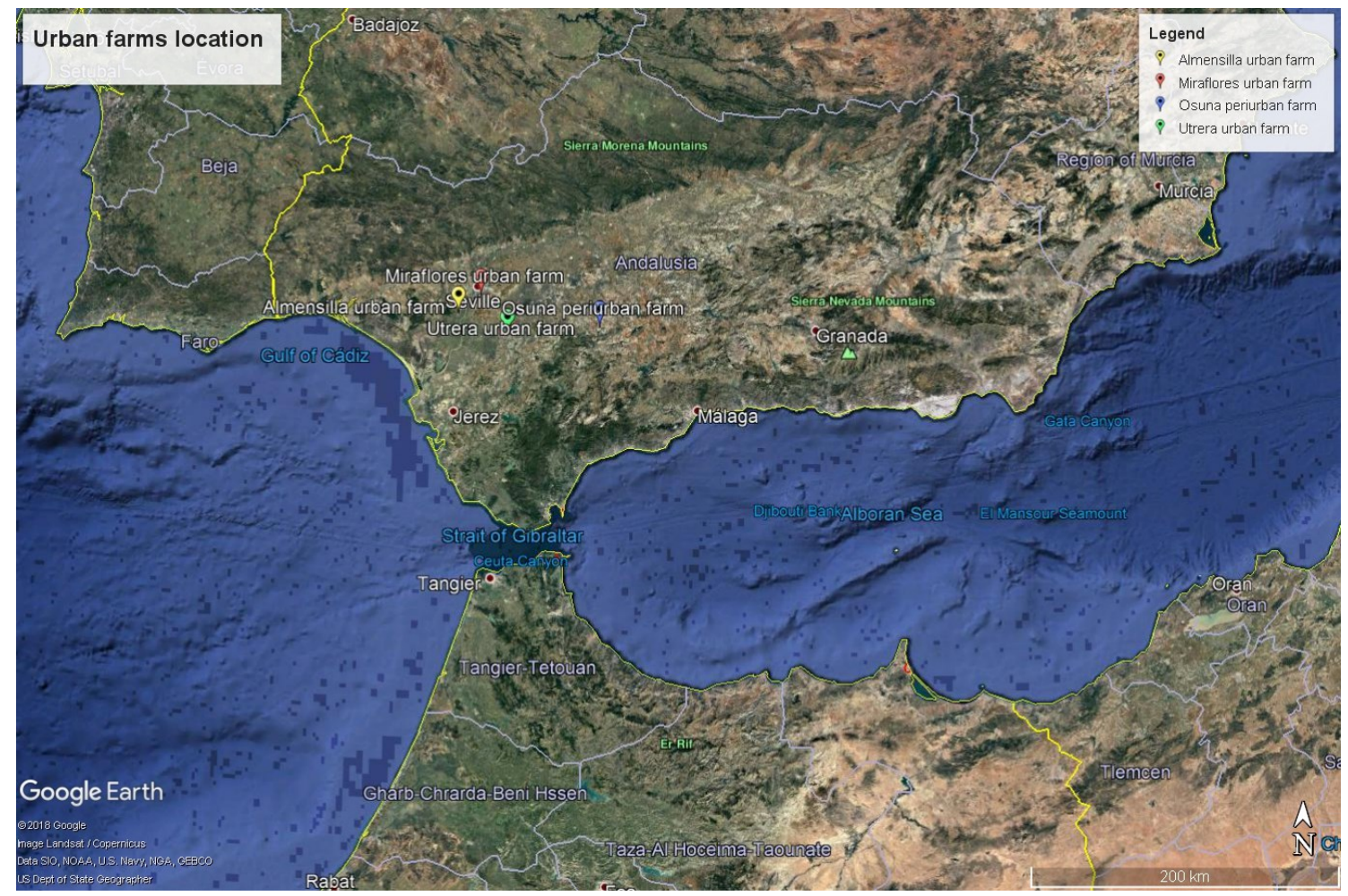

Figure 1. Location of the urban farms in Southern Spain. 


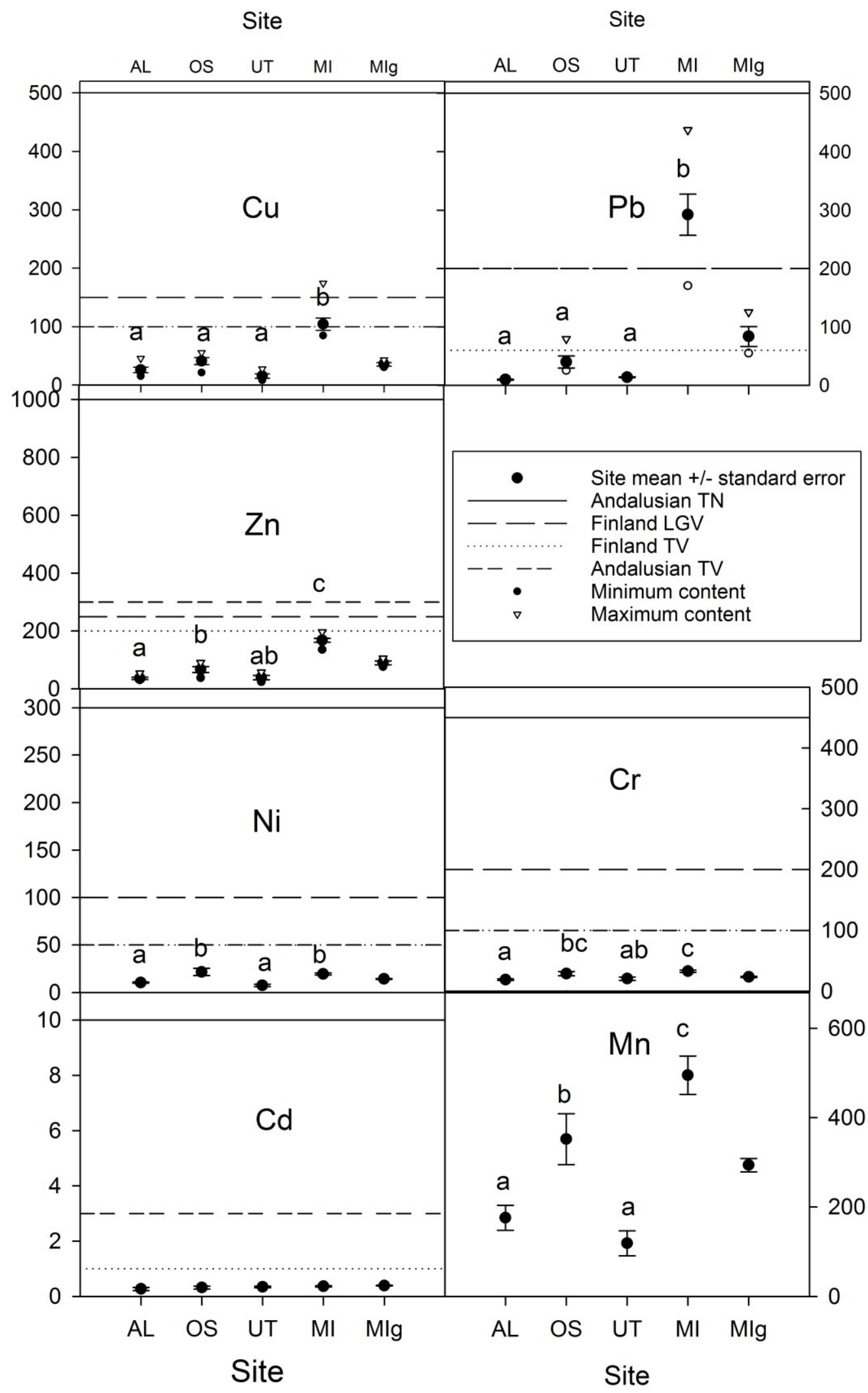

Figure 2. Soil metal concentrations (average, maximum, minimum and standard error in $\mathrm{mg} \mathrm{kg}{ }^{-1}$ ) in the urban farms (AL: Almensilla; OS: Osuna; UT: Utrera; MI: Miraflores Park in Sevilla city, MIg: garden area in Miraflores Park) and guideline values: TV 
(Threshold value indicates needing for further assessment) and TN, (Treatment needed) following Andalusian guidelines (Aguilar-Ruíz et al. 1999) and TV and LGV (Lower guideline value indicates ecological or health risks) following Finland regulation (MEF, 2007). Different letters on top of the points indicated significant differences among mean values following Tukey test $(\mathrm{p}<0.05)$.

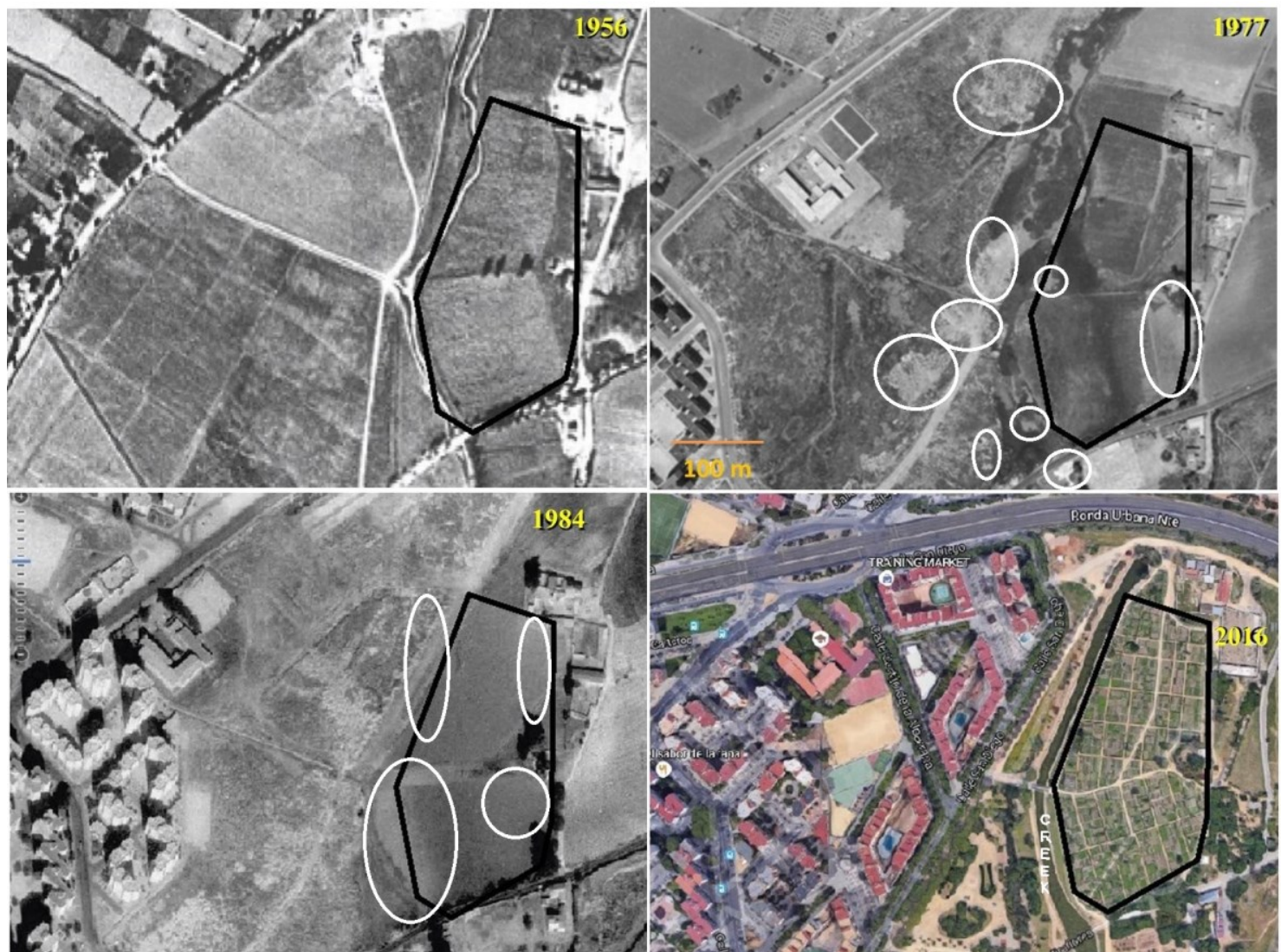

Figure 3. Land transformation in Miraflores (MI) park from 1956 (left upper corner) to present time (right lower corner) (The images of the years 1956, 1977 and 1984 were adapted from Red Rediam (Consejería de Medio Ambiente, 2012); the image of 2016 was taken from Google Earth, Google). 


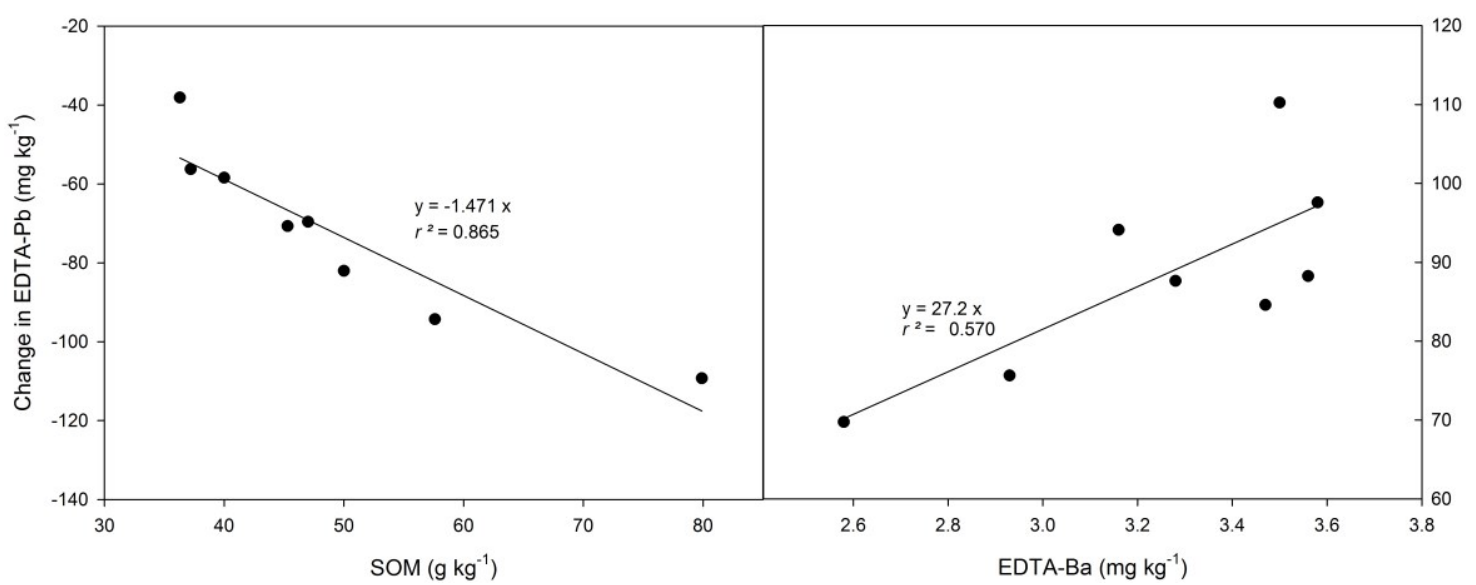

Figure 4. Relationships of the EDTA-Pb extractable concentration for the Miraflores

(MI) soil samples with soil organic matter concentration (left) and with soil EDTA-Ba extractable concentration (right) corresponding to equation 1. 


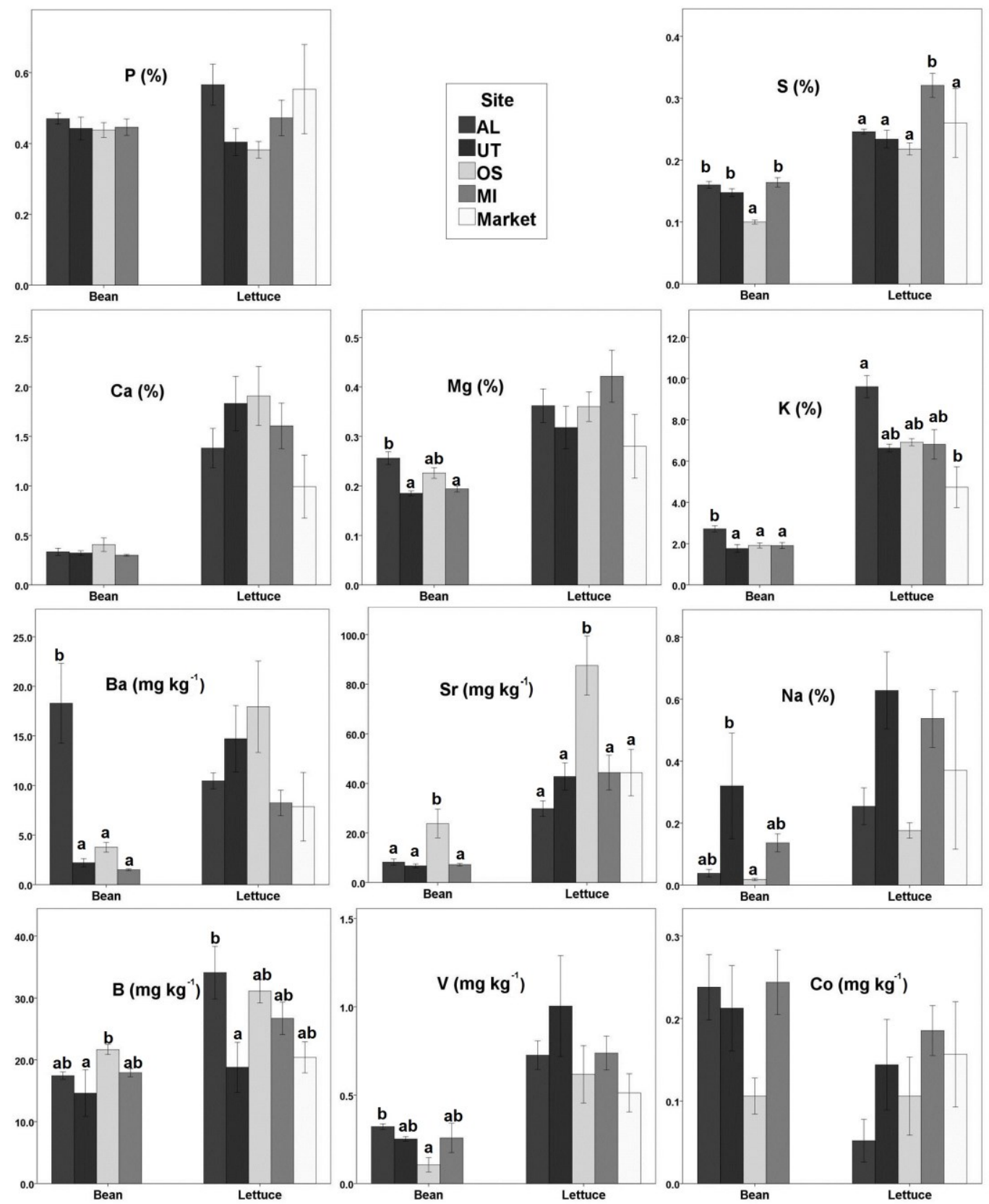

Figure 5. The average concentration of plant nutrients ( \pm standard error) in the pods of beans and in lettuce samples corresponding to the different urban farms and commercial lettuce samples. Different letters on top of the bars indicated significant differences among mean values following Tukey test $(\mathrm{p}<0.05)$. 


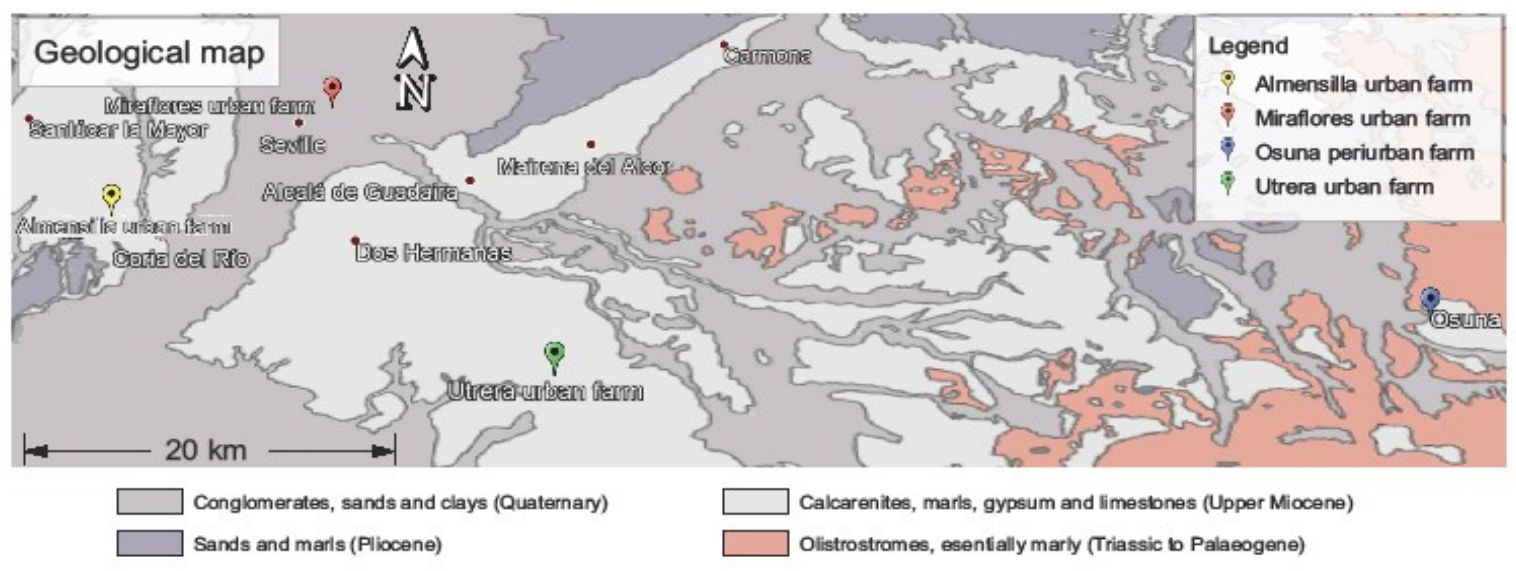

Figure S1: Geological map of the area (obtained from Consejería de Medio Ambiente, 2005). 


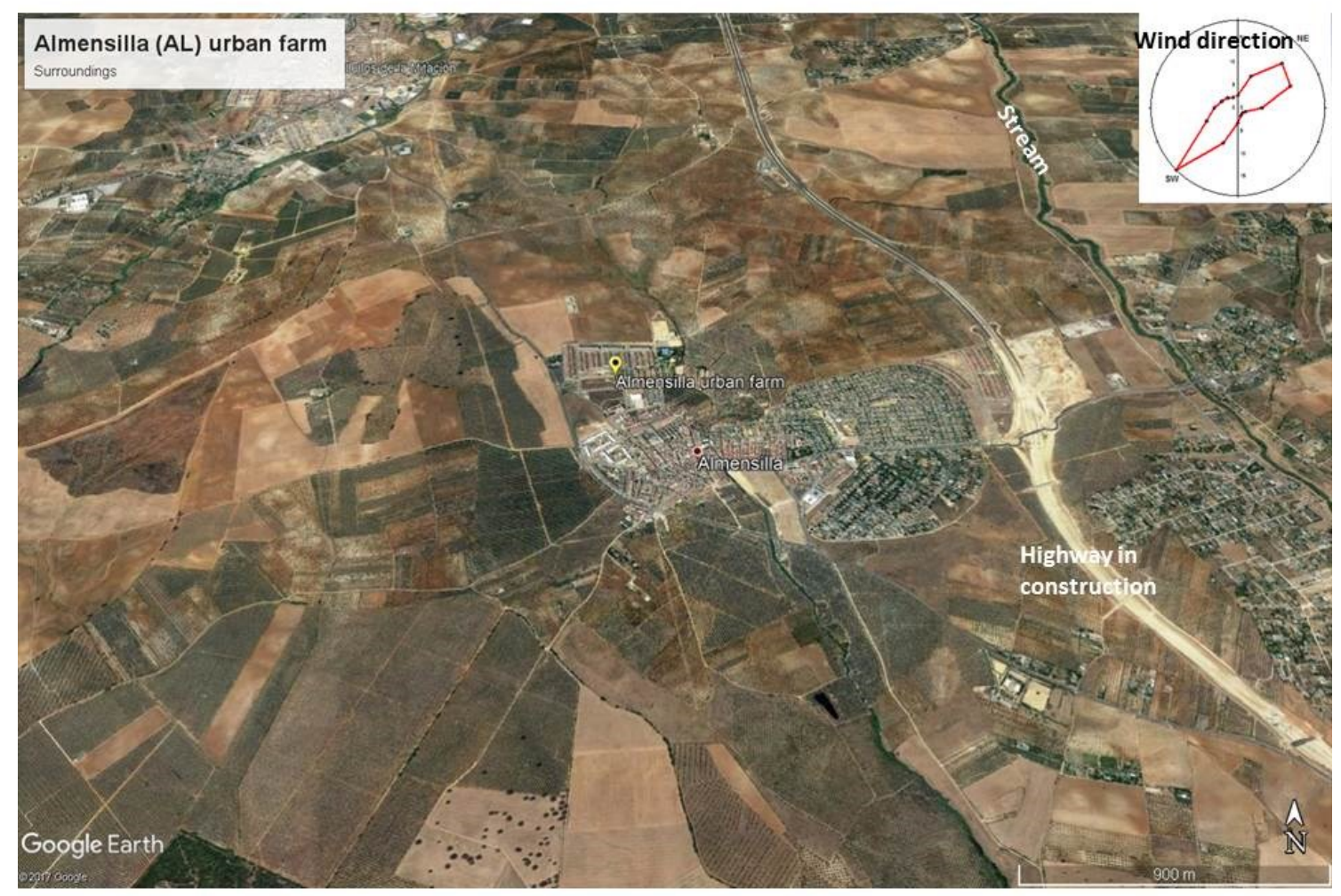

Figure S2: Almensilla urban garden. Surroundings and sampling points.

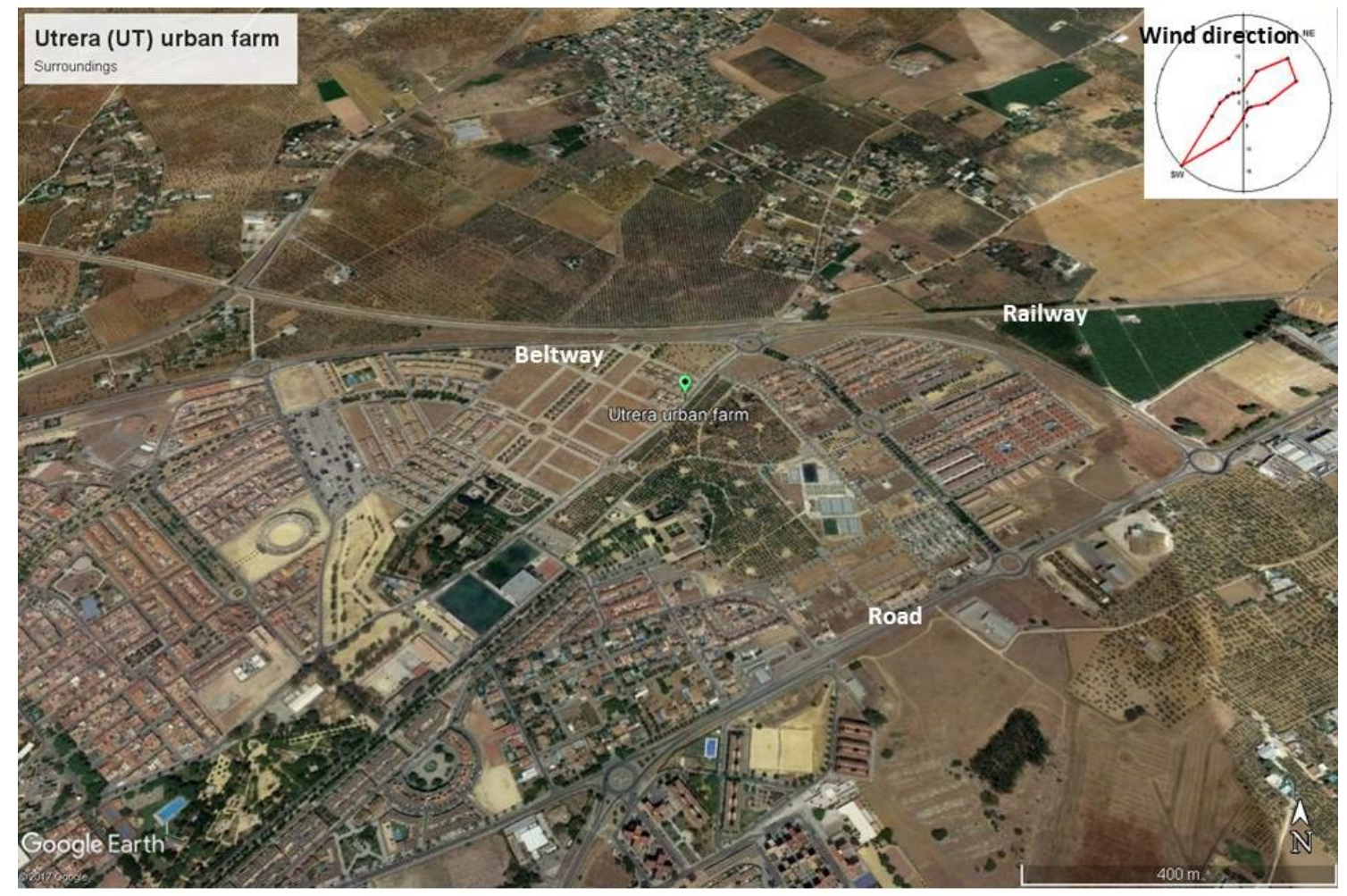

Figure S3: Utrera urban garden. Surroundings and sampling points. 


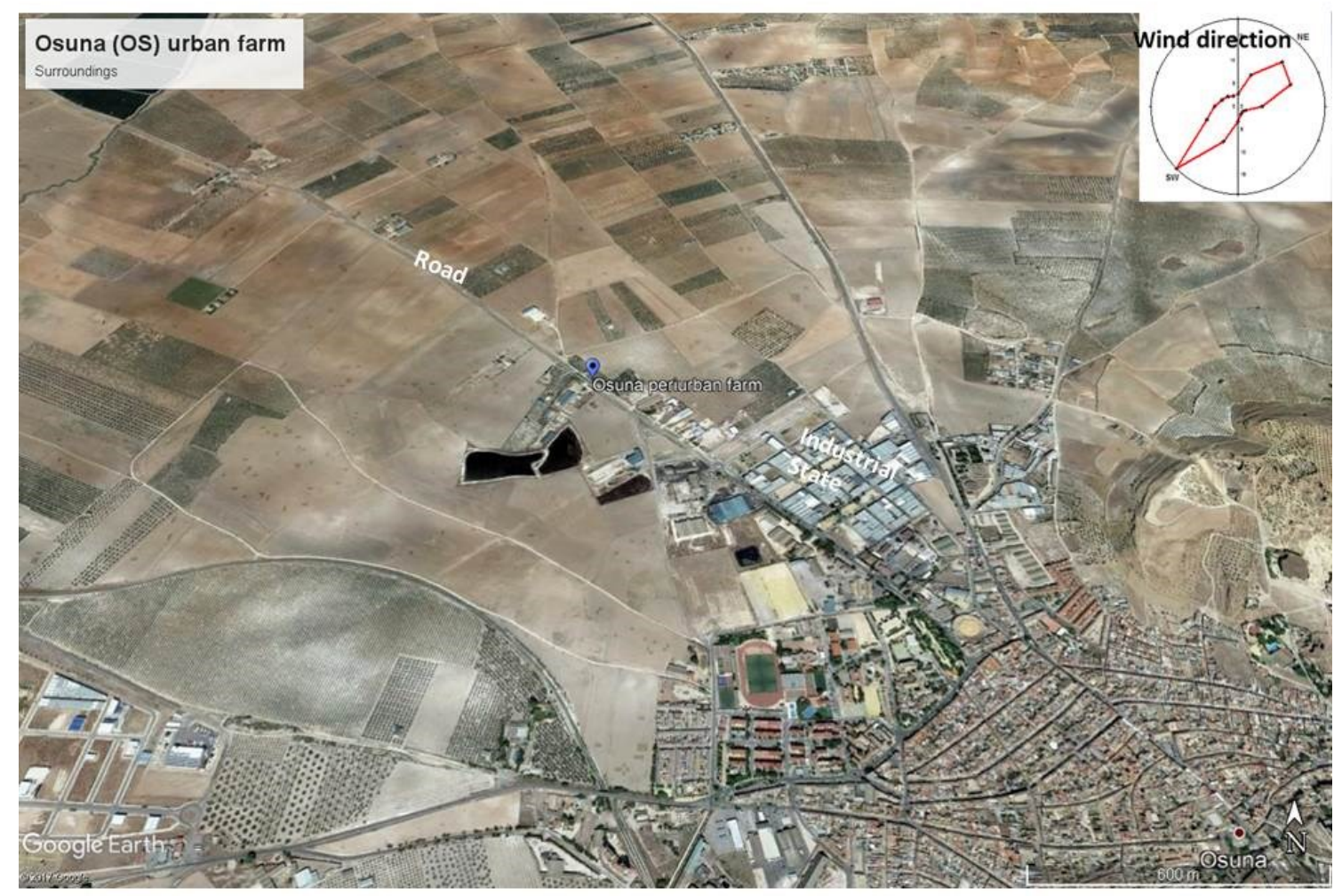

Figure S4: Osuna periurban farm. Surroundings and sampling points.

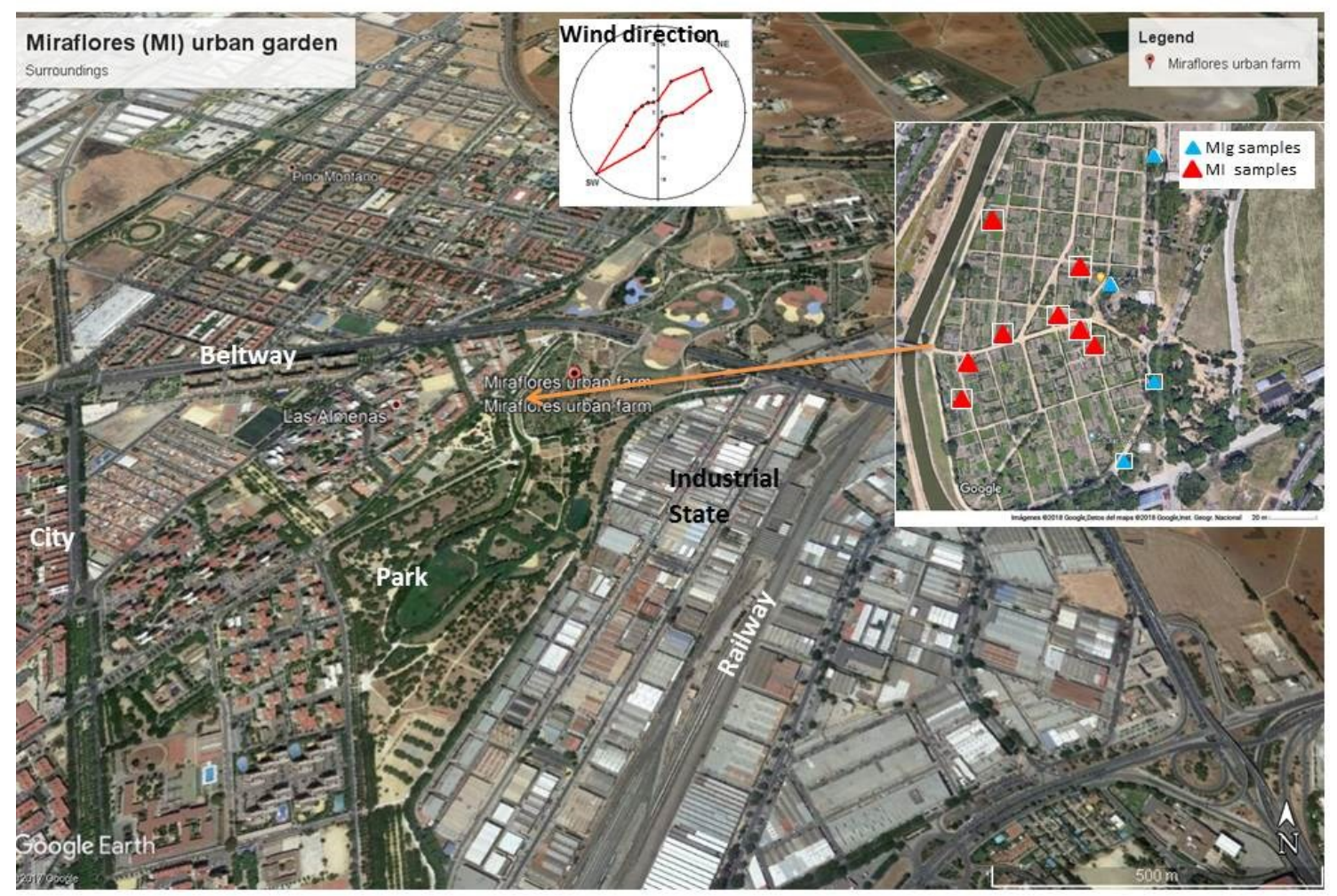

Figure S5: Miraflores urban garden at Sevilla city. Surroundings and sampling points. 

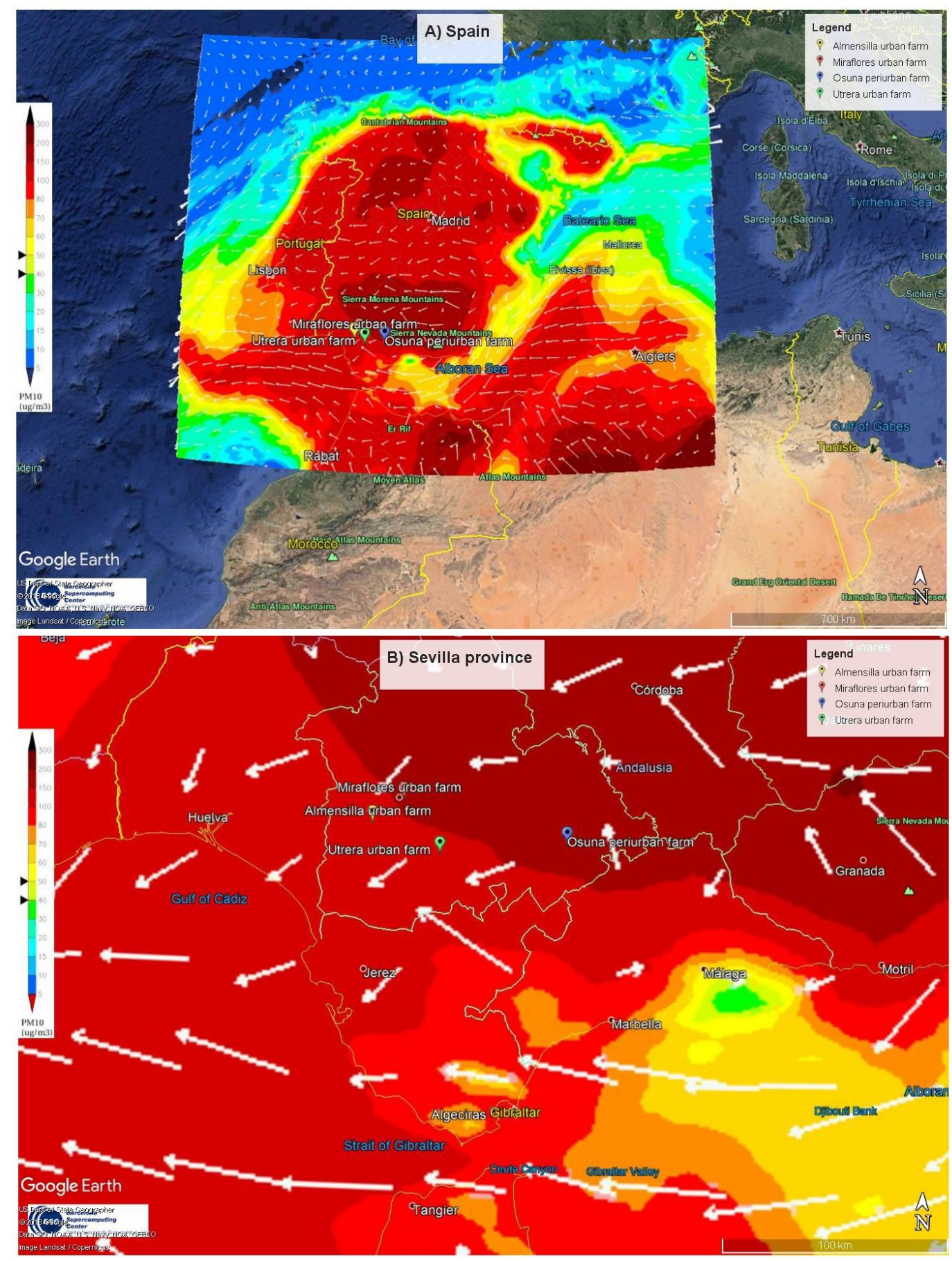

Dust deposition in the area

Figure S6: Wind direction and PM10 deposition in Spain (left) and Sevilla province (right) at February 22, 2016, 6:21 a.m. (obtained from Google Earth and Barcelona Dust Forecast Center- Agencia Estatal de Meteorología. 2016). 